\title{
LA EMIGRACIÓN A FRANCIA DEL CLERO LIBERAL ESPAÑOL: 1823-1834
}

\begin{abstract}
Aline Vauchelle*
Rebatiendo las tesis esgrimidas por la historiografia integrista y luego recogidas por la franquista, destacados historiadores ya han demostrado que, a principios del siglo XIX, mientras en España se intentaba sustituir el Antiguo Régimen por un Estado moderno, de tipo liberal burgués, una parte del clero respaldó decididamente este proceso revolucionario ${ }^{1}$. Con el presente estudio sobre los eclesiásticos españoles que encontraron asilo en Francia después del Trienio liberal, esperamos contribuir a profundizar los conocimientos sobre quiénes fueron estos sacerdotes que se adhirieron a la causa constitucional hasta verse forzados al destierro y sobre sus condiciones de vida en el país galo.

Para llevar a cabo semejante trabajo, el investigador tiene a su alcance importantes fuentes en el Archivo Nacional de Francia en París. Primero, en el fondo de Police Générale (F19') correspondiente al ministerio del Interior y donde se halla, en especial, una riquísima colección de expedientes individuales sobre los españoles emigrados en Francia entre 1822 y 1835 . Además de ese impresionante número de legajos -cuya consulta diaria lamentablemente se ve drásticamente limitada por la Dirección del Archivo-, están a disposición los documentos de la Grande Aumônerie y de la Police des Cultes $\left(\mathrm{F}^{19}\right)$ que corresponden al ministerio de Asuntos Eclesiásticos y Cultos, creado por Napoleón, en 1804.

Desde luego, sería quejarse de vicio deplorar la excesiva abundancia de documentos que encierran los expedientes individuales formados por la Dirección General de Policía, departamento encargado de escrutar los hechos y milagros de la población y, con mayor meticulosidad si cabe, de los sospechosos, entre quienes destacaban los

\footnotetext{
* Universidad de Rouen, Criar.

1. Véase en particular Cárcel Orti, V., "Masones eclesiásticos durante el Trienio liberal (1820-1823)" en Archivum historiae pontificae $n^{\circ}$ 9, Roma, 1971, p. 249-277; La Parra López, E., El primer liberalismo españoly la Iglesia. Las Cortes de Cádiz, Instituto Juan Gil-Albert,Alicante, 1985, 320 p.; Dufour, G.,Juan Antonio Llorente en France (1813-1822), Droz, Genêve, 1982, 375 p.; del mismo autor: Un liberal exaltado en Segovia: el canónigo Santiago Sedeño y Pastor (1769-1823), Universidad de Valladolid, 1989, 112 p. y Sermones revolucionarios del Trienio liberal (1820-1823), Instituto Juan Gil-Albert, Alicante, 1991, 211 p..
} 
extranjeros refugiados. Esa puntillosa vigilancia, rayana en paranoia, la monarquía de la Restauración la ejercía mediante una tupida red de prefectos y subprefectos que tenían a su cargo informar detenida y puntualmente al Ministro del Interior sobre las efectivas o posibles amenazas contra el orden público. De lo cual resulta un considerable papeleo que, si bien depara jugosos testimonios, a veces también se revela redundante y por ende totalmente vano para el lector. Quizá constituyan el mayor exponente de tanto esmero el sinnúmero de atestados expedidos por la policía en todas y cada una de las etapas que recorría un asilado, cuando lograba el permiso de desplazarse de una ciudad a otra, viéndose señalar un itinerario forzoso. Si a esto se añade que los sabuesos y chupatintas franceses tenían de la ortografia española conocimientos más que aproximados y que no entendían el sistema español de doble apellido, el investigador tiene que vérselas con nombres afrancesados o equivocados, así como con apellidos estropeados que forman un embrollo a veces dificil de desenmarañar. Por eso, en la lista de los eclesiásticos españoles refugiados en Francia que ofrecemos al final y según el famoso aforismo, no pretendemos que "estén todos los que son", pero por lo menos, hemos procurado que "sean todos los que están", renunciando a incluir en el elenco a los sacerdotes emigrados cuya identificación resulta incierta y cuyo compromiso con el liberalismo deja lugar a dudas.

Ya hemos mencionado los fondos de la Grande Aumônerie, a los que hemos acudido como complemento. El cargo de Limosnero Mayor, de enorme prestigio y no menor influjo dado que abarcaba el ejercicio de la plenitud de la jurisdicción episcopal en los Reales Sitios, fue suprimido en 1790, cuando la Revolución. Restablecido por Napoleón en 1804, le correspondió entonces la Superintendencia del servicio del culto en la corte imperial y en el ejército, antes de su segunda abolición por Luis Felipe en 1830. Los documentos procedentes de la Grande Aumônerie, que abarcan desde el Año XII (1804) hasta 1830, versan esencialmente sobre la disciplina eclesiástica, recogiendo las denuncias de los fieles de París contra los sacerdotes poco cumplidores o acusados de tener malas costumbres u opiniones sospechosas. Nada hemos encontrado en ellos acerca de los clérigos liberales españoles. En cuanto a los papeles del ministerio de Asuntos Eclesiásticos y Cultos, -instituido por el Emperador con vistas a controlar a los eclesiásticos y, a continuación, muy eficaz durante la Restauración para mejorar la situación del clero $^{2}$-, consisten mayormente en informes dirigidos por los obispos a los prefectos. Hemos comprobado en los distintos sondeos que hemos realizado, que confirman los documentos emanados de la Dirección de la Policía, sin aportar mucha novedad.

Terminada la guerra de la Independencia, ya se habían refugiado en Francia algunos sacerdotes liberales españoles, a consecuencia de la derogación de la constitución de Cádiz por Fernando VII, en 1814. Con todo, entre los españoles entonces asilados, eran muy pocos los miembros del clero partidarios del liberalismo. Por eso, tan sólo hemos registrado cuatro casos de eclesiáticos que ya habían emigrado después de la francesada y que tuvieron que hacerlo por segunda vez tras la liquidación del Trienio, siendo los cuatro, por más señas, religiosos exclaustrados ${ }^{2 b i s}$. En 1823 , con la caída del

2. Lebrun, F (bajo la dirección de), Histoire des catboliques en France du $X V^{\circ}$ siècle à nos jours, Privat, Pari s, 1980, p. 308-309.

2bis. Se trata de Gabriel Arrambibe, Ramón Nuño, Cristóbal Pueyo y Juan Riera, respectivamente $\mathrm{n}^{\circ} \mathbf{8}$, 89,104 y 107 en nuestra lista. 
régimen constitucional, la emigración de clérigos españoles fue un fenómeno mucho más significativo, tanto numérica como ideológicamente. De hecho, en el Trienio constitucional se puso verdaderamente en marcha la reforma de la Iglesia española, que las Cortes de Cádiz tan sólo habían podido esbozar por motivo de la situación bélica. Medidas de gran calado como la -esta vez definitiva- abolición de la Inquisición, la reforma de las órdenes religiosas, la supresión de monacales y puesta en venta de sus bienes, la reducción del diezmo en una mitad, la supresión del fuero eclesiástico lesionaban peligrosamente los intereses de la Iglesia ${ }^{3}$. Por consiguiente, el que algunos sacerdotes apoyaran semejante política constituía un poderoso compromiso. Y lo demuestra claramente el alto precio que luego les costó

Al efectuar anteriores investigaciones sobre los españoles refugiados en Francia a principios del siglo $\mathrm{XIX}^{5}$, había llamado nuestra atención la presencia, al parecer digna de consideración, de clérigos liberales tras el Trienio. Lo cual nos incitó a proseguir las pesquisas y hemos de confesar que la lista de 130 eclesiásticos liberales emigrados que hemos podido levantar rebasa nuestras expectativas y esperanzas iniciales. Por supuesto, no deja de ser una proporción ínfima con respecto a los impresionantes efectivos del clero español recogidos en el censo de 1797 -el último fidedigno a ojos del profesor Revuelta ${ }^{6}$ - y que arroja un total de 134.675, entre seculares y regulares. Hasta teniendo en cuenta que, de 1808 a 1820 , se había rebajado en 13.000 la cifra de los regulares varones ${ }^{7}$, la relación sigue siendo mínima. Pero a nadie puede sorprender que los sacerdotes adictos a las ideas innovadoras fueran una minoría dentro del clero español de la época. Además, al concluir el Trienio constitucional, no todos los clérigos liberales tuvieron la oportunidad, o quisieron, exiliarse y muchos sufrieron la represión en España.Tampoco cabe olvidar que, en 1823, numerosos constitucionales españoles huyeron a Inglaterra, -donde se asentaron algo más de mil ${ }^{8}$-, a Bélgica $\mathrm{e}$ incluso, en algunos casos, a América del Sur. Los eclesiásticos que abandonaron España fueron, pues, a engrosar las filas de la emigración en estos países.

En cambio, resulta muy significativo que esta cifra de 130 sólo sea ligeramente inferior al número de eclesiásticos afrancesados que se refugiaron en Francia al acabar la guerra de la Independencia: éstos eran 152, según los datos publicados por Gérard Dufour". Ahora bien, en 1813, era lógico que los secuaces del "rey intruso" José Bonaparte, se pusieran a salvo en Francia -hasta batiéndose en retirada con los convoyes del ejército josefino-, cuando las principales potencias europeas estaban coaligadas contra Napoleón. Los afrancesados, por lo tanto, no tenían otros países a dónde

3. Cuenca Toribio, J.M., "La Iglesia española en el Trienio constitucional (1820-1823)" en Hispania sacra XVIII, CSIC, Madrid, 1965, p. 333-362 y Revuelta González, M., Política religiosa de los liberales en el siglo XIX, Trienio constitucional, CSIC, Madrid, 1973, XIII + 515 p.

4. Revuelta González M., Ibid., p. 367 sig.

5. Vauchelle Haquet, A. et Dufour, G., "Les Espagnols naturalisés français et les Espagnols ayant obtenu l'autorisation de fixer leur domicile en France de 1814 à 1831" en Exil politique et migration économique: Espagne et France aux XIX-XX $X^{\circ}$ siècles, CNRS, Paris, 1991, pp. 31-51.

6. Revuelta González M., op. cit., p. 36.

7. Ibid., p. 39.

8. Llorens, V., Liberales y románticos. Una emigración española en Inglaterra (1823-1834), Castalia, Madrid, 1979, p. 23.

9. Dufour, G. "La emigración a Francia del clero afrancesado" en El clero afrancesado, Université de Provence, 1986, p. 167-206. 
buscar asilo. Mientras, al contrario, en 1823, Francia era la que había mandado a los Cien Mil Hijos de San Luis a acabar con la experiencia constitucional española, a iniciativa de la Santa Alianza. De ahí que el grueso de los emigrados se marchara entonces a encontrar cobijo en Inglaterra, cuyo gobierno no respaldó la expedición militar francesa. En estas condiciones, que en Francia estuvieran refugiados nada menos de 130 miembros del clero, o sea de un colectivo en su inmensa mayoría hostil al liberalismo, sin duda merece examen.

Según Gregorio Marañón, después del Trienio, los liberales españoles fueron 20.000 en abandonar su patria ${ }^{10}$. Aunque la cifra le parezca algo exagerada, Rafael Sánchez Mantero admite que la oleada migratoria del 23 fue la más importante del siglo XIX español, tanto en el aspecto cuantitativo como en el cualitativo ${ }^{11}$. Como hemos dicho, los constitucionales más señalados se dirigieron entonces hacia Inglaterra. Sin embargo, en Francia estuvieron también numerosos españoles. Además de un grupo de estadistas, nobles y burgueses adinerados - una élite de difícil cuantificación-, estaba "albergado" otro colectivo, integrado por los prisioneros de guerra del ejército liberal. Incluidos en las capitulaciones de las distintas ciudades que cayeron ante la tropas del duque de Angulema, eran 12.459, entre ellos 1.500 oficales $^{12}$. Fueron repartidos en 32 depósitos, 25 para los suboficiales y soldados y 7 para los oficiales. Para éstos se estableció, en particular, un depósito principal en Bourges, en el centro del país ${ }^{13}$. Luego que el monarca español se dignó otorgar una amnistía, el $1^{\circ}$ de mayo de 1824, se desmantelaron dichos depósitos. Quienes entonces optaron por permanecer en Francia fueron en adelante considerados como refugiados y ya no como prisioneros. Lo cual acarreaba la pérdida de la paga, no por corta menos imprescindible, que les abonaba el ministerio de Guerra francés ${ }^{14}$. Esta medida afectó a 43 de nuestros 130 eclesiásticos (nada menos del 33\%): los capellanes de los batallones liberales, conducidos a Francia como prisioneros y que, asimilados al grado de capitán, habían de recibir una asignación de 600 francos al año.

Ahora bien, fue tan restringido y mezquino el indulto concedido por Fernando VII que casi sólo los soldados rasos pudieron regresar sin temer verse represaliados. En mayo de 1824, únicamente en Bayona fueron 5163 los que cruzaron la frontera ${ }^{15}$. Pero, en el caso concreto de los clérigos, el artículo $11^{\circ}$ del Real Decreto rezaba:

"Los M. RR. arzobispos y los RR. obispos en sus respectivas diócesis, después de publicado el presente indulto,... inspeccionarán la conducta de los párrocos y demás eclesiásticos existentes en su territorio para tomar las providencias que les dicte su celo pastoral por el bien de la Iglesia y del Estado"16.

10. Marañón, G., "Influencia de los franceses en la política española a través de los emigrados" en Obras completas, Tomo III, Espasa Calpe, Madrid, p. 643.

11. Sánchez Mantero, R., Liberales en el exilio. (La emigración política en Francia en la crisis del Antiguo Régimen), Rialp, Madrid, 1975, p. 15.

12. Ibid., p. 16.

13. Ibid., p. 38-39.

14. Ibid., p. 72 y 125.

15. Ibid., p. 72.

16. Historia de la vida y del reinado de Fernando VII,Tomo III, Imprenta de Repullés, Madrid, 1842, p. 450. 
No podía el soberano exhortar más claramente a las autoridades religiosas a la represión contra sus subordinados que habían manifestado simpatía por el régimen constitucional.Y aquéllas efectivamente no se hicieron de rogar.

Tras la disolución de los depósitos, donde se les podía fácilmente controlar, la policía francesa redobló la vigilancia hacia los ex prisioneros. Pero, sólo uno de los capellanes le pareció bastante peligroso para ser expulsado, en mayo de 1824. Agustín Ximénez Marcos, navarro de Eibar, ex capellán de la fortaleza de Pamplona, había hecho gala de opiniones tan exaltadas que, cuando los Cien Mil Hijos de San Luis ingresaron en la plaza, lo encontraron encarcelado ya. El pueblo manifestaba resentimientos tan profundos en su contra que se juzgó prudente sacarlo al amanecer, antes de llevarlo a mansalva, a San Juan Pie de Puerto. Luego, las autoridades militares francesas lo mandaron al fuerte de Briançon, donde estaban recluidos los prisioneros a quienes se quería vigilar más estrechamente.Ya desmantelados los depósitos, Ximénez Marcos pidió permiso para residir en Agen, pero tildado de "revolucionario muy exaltado", se le mandó salir del reino.A pesar de todo, en octubre de 1826, todavía vivía en la región de Pau, escondido y dedicándose a copiar la prensa liberal francesa. Sólo en febrero de 1827 acabó zarpando hacia Portugal, después de que una colecta entre sus compatriotas asentados en Bayona le permitiera reunir el precio de su pasaje ${ }^{17}$.

Al mismo tiempo que estos 43 capellanes prisioneros de guerra, habían entrado en Francia otros 53 eclesiásticos en busca de asilo.Y más tarde, entre 1825 y 1831, ingresaron 30 , después de verse sometidos a amenazas, represalias e incluso penas de reclusión en conventos. De hecho, a los pocos días de ser restablecido como rey "neto", Fernando VII había expedido, el 6 de octubre de 1823, una Real Orden a tenor de la cual a los clérigos "que ha(bía)n sido agentes de la facción desorganizadora cuidar(i)an las autoridades respectivas de ponerlos en reclusión"18, lo que se cumplió con todo rigor. No obstante, por interés propio y también para satisfacer a las potencias de la Santa Alianza, Francia y Rusia en especial, el monarca se negó a restaurar por segunda vez la Inquisición. Pero no impidió que, en 1825, algunos obispos instituyeran en sus diócesis unos tribunales que sirvieron de sustituto al extinto Santo Oficio. Recordemos que, en julio de 1826, luego de sentenciado por deísta por una de estas "Juntas de fe", el maestro de escuela Cayetano Ripoll fue ejecutado en Valencia". Por lo tanto, las amenazas y persecuciones que alegaron los eclesiásticos fugitivos para ser admitidos en Francia no eran nada fantasmagóricas. Entre otros casos, lo demuestra meridianamente el de Francisco Cristóbal, nativo de Valencia, doctor en teología y vicario de la Colegiata de San Felipe de Játiva, recluido durante diez meses en un monasterio en Cartagena, antes de verse desterrado a siete leguas de Játiva, privado de su cargo de vicario y hasta del permiso de rezar misa por la Junta de fe,"más terrible que el antiguo tribunal de la Inquisición", según afirmaba ${ }^{20}$.

En condiciones menos apuradas, de 1830 a 1832, llegaron otros 4 clérigos, 3 procedentes de Inglaterra y uno de Bélgica, países donde se habían asilado inicialmente.

17. Archivo Nacional de Francia (en adelante A.N.F.): Série F': Police Générale. Espagnols réfugiés. 1822-1832: dossiers individuels: legajo 11985.

18. Citado por Dufour, G., Sermones... p. 54.

19. Marti Gilabert, F, Iglesia y Estado en el reinado de Fernando VII, Eunsa, Pamplona, 1994, p. 166-168. 20. $F^{7} 12089 n^{\circ} 745$. 
A semejanza de los demás emigrados liberales que a la sazón se trasladaron a Francia, lo hicieron movidos por las esperanzas políticas nacidas de la Revolución de Julio de 1830 y de la consiguiente proclamación de Luis Felipe de Orléans como rey de los franceses. Pero también fueron atraídos por motivos más prosaicos: la perspectiva de cobrar los subsidios que, el 16 de diciembre de 1829, Carlos X decidió abonar a los ex prisioneros españoles - con vistas a amansar a los más inquietos y hacerles desistir de forjar constantes intringas con los liberales franceses ${ }^{21}-$, y que luego la monarquía orleanista extendió generosamente a todos los refugiados.

¿Quiénes eran estos sacerdotes españoles adictos al liberalismo que no tuvieron más remedio que vivir varios años exiliados en Francia?

Desgraciadamente, en no pocos casos, la policía se limitó a mencionar su calidad de "eclesiástico -o sacerdote- español", sin especificar nada más.

En lo que se refiere a los 43 capellanes de regimientos constitucionales, los documentos consultados no suelen indicar los cargos que hayan podido desempeñar antes de ponerse al servicio del ejército. Sólo para 8 de ellos, se especifica que eran ex monjes secularizados. Además de estos capellanes, otros 18 de los eclesiásticos residentes en Francia eran religiosos exclaustrados: o sea 26 (el 20\% del total de 130). Se habían acogido a la ley de supresión de monacales y de reforma de regulares, votada por las Cortes el $1^{\circ}$ de octubre de 1820 , cuyo artículo 13 estipulaba:

"El Gobierno protegerá por todos los medios que estén en sus facultades la secularización de los regulares que la soliciten, impidiendo toda vejación o violencia por parte de sus superiores; y promoverá que se les habilite para obtener prebendas y beneficios con cura de almas o sin ella" ${ }^{22}$.

En los cortos años de vigencia del sistema constitucional, esta medida propició algo más de 8.000 secularizaciones, cifra tan considerable con respecto a los 30.000 religiosos con que contaba entonces España, que Manuel Revuelta González no vacila en hablar de auténtica "desbandada" ${ }^{23}$. Pero, distaron mucho de cumplirse los buenos deseos de las Cortes en lo tocante a la colocación de los ex monjes. Con los beneficios ni podían soñar dado que las propias Cortes los habían suspendido. En cuanto a los curatos, salvo contadas excepciones de obispos liberales o comprensivos, las autoridades eclesiásticas se mostraron reacias a concedérselos, por lo cual la mayoría de los secularizados pasaron estrecheces. Si a la penuria económica se añade que tuvieron que sufrir no sólo la hostilidad de sus hermanos en el sacerdocio sino también la de muchos fieles, su suerte resultó de todo punto dramática ${ }^{24}$. Sometidos a tales vejaciones en los años de gobierno liberal, ni que decir tiene que se exponían a penas y castigos con la restauración monárquica. El citado decreto de 6 de octubre de 1823 mandaba expresamente que los prelados destituyeran a los secularizados de los curatos o capellanías que hubieran obtenido y les privaran de las licencias de predicar y confesar. En efecto, el que unos frailes se hubieran marchado del monasterio, donde otrora probablemente se habían metido -o los habían metido sus padres- sin sentir

21. Citado por Sánchez Mantero, R., op. cit., p. 127-129.

22. Citado por Revuelta Gónzalez, M., op. cit., p. 388.

23. Ibid., p. 293.

24. Ibid., p. 331-332. 
verdadera vocación, fue automáticamente considerado como una manifestación de adhesión a la causa constitucional. De ahí que tuvieran poderosos motivos para ponerse a salvo en Francia. Lo entendió claramente el prefecto de los Pirineos Orientales, quien informando sobre la llegada a Perpiñán del ex dominico barcelonés Juan Viguer el 4 de mayo de 1824, especificaba que éste se había comprometido en España con los revolucionarios por haber dejado su convento ${ }^{25}$.

Otro testimonio de la lamentable situación de los secularizados lo da el patético caso de Tecla López de Angulo. Nacida en Briviesca, religiosa de las Huelgas Reales en Burgos, abandonó el claustro en 1822. Vino a Francia en 1825 para escapar de las persecuciones cuyo blanco era. Pero, a diferencia de sus hermanos, ni siquiera le quedó el recurso de decir algunas misas para asegurar su sustento. Así, tuvo que desenvolverse en París trabajando con sus manos. Sumida en la miseria, solicitó y obtuvo una ayuda diaria de 1,50 franco en 1831 y sólo regresó a su patria en diciembre de 1834 cuando, a consecuencia de la amnistía otorgada el 23 de octubre de 1833 por la regente María Cristina, ya estuvo segura de no tener nada que temer de las autoridades eclesiásticas $^{26}$. Sin embargo, no pudiendo afirmar a ciencia cierta la adhesión de esta religiosa al liberalismo, no la incluimos en nuestra lista.

Aparte de los 8 ex regulares que obtuvieron una capellanía militar, sólo para 4 de los demás secularizados hemos podido comprobar que fueron "recolocados" durante el Trienio. Domingo Bergay, ex dominico barcelonés, logró ser nombrado teniente de cura en la parroquia de San Miguel ${ }^{27}$. Juan Costa, ex fraile cuya orden religiosa desconocemos, también fue teniente de cura en $\mathrm{Vich}^{28}$. El ex capuchino Hermenegildo Llorens, consiguió un curato en Olot antes de ser trasladado a otro en Hospitalet ${ }^{29}$. Y el ex mercedario navarro Ramón Nuño, de vuelta de su primer exilio en Francia, se hizo cargo de la parroquia de San Ginés, en Madrid ${ }^{30}$. La escacez de semejantes datos nos parece ser un fiel reflejo de los obstáculos con que tropezaron los antiguos monjes a la hora de integrarse en el clero secular. En cambio, no será mera casualidad que estos casos correspondan a diócesis en que la jerarquía religiosa respaldó las reformas liberales. Luis Gregorio López del Castrillo, obispo auxiliar de Madrid desde 1815, no sólo fue diputado a Cortes en 1820, sino que fue uno de los principales artífices de la reforma de regulares ${ }^{31}$.Y en Barcelona, tras la renuncia del amedrentado prelado Pedro Sichar, ejerció gran influjo el liberal Félix Torres Amat, miembro de la Junta de gobierno de la Ciudad Condal en 1820 y luego obispo electo de la misma, aunque se negó a aceptar la sede ${ }^{32}$.

Es un hecho conocido que muchos de los eclesiásticos favorables al régimen de las Cortes eran miembros del clero culto. Lógicamente pues, además de 10 curas párrocos, 26 de los sacerdotes liberales refugiados en Francia -un nada despreciable $20 \%$ de nuestra lista-, descuellan por su alto nivel de preparación intelectual y por las

25. $\mathrm{F}^{7} 12034 \mathrm{n}^{\circ} 1027$.

26. $F^{7} 12077 n^{\circ} 100$.

27. $\mathrm{F}^{7} 12 \mathrm{O} 43 \mathrm{n}^{\circ} 1281$.

28. $\mathrm{F}^{\urcorner} 12015 \mathrm{n}^{\circ} 511$

29. $\mathrm{F}^{7} 12014 \mathrm{n}^{\circ} 464$.

30. F $12050 \mathrm{n}^{\circ} 1623$.

31. Véase Revuelta González, M., op. cit., p. 127-177.

32. Ibid., p. 127, 346-347. 
dignidades que ocuparon antes de emigrar. Entre ellos sobresalen en particular 5 profesores, 1 protonotario, 2 beneficiados, 2 arcedianos, 1 vicario general, 10 canónigos de los que 4 son dignidad y 2 obispos.

Por ejemplo, no dejaría de ser culto Juan Ferrer, doctor en teología, beneficiado de la Catedral de Mallorca, protonotario y juez de la Iglesia romana. Perseguido por sus opiniones políticas, se marchó para Francia en 1828. En 1831, el gobierno de la monarquía de Julio le otorgó un subsidio de 45 francos mensuales puesto que no le daba abasto la misa diaria que decía en la parroquia de Saint-Méry. Por desgracia suya, todavía residía en París en 1835, porque allí fue asesinado por un tal Benito Pereira, oficial de ebanista. Según la policía, se trataba de un ex monje español, ya autor de diversos hurtos, y cometió el crimen para robar a Ferrer, pues en el momento de su arresto, llevaba encima el reloj de éste ${ }^{33}$.

Destacados cargos ostentó Antonio de la Cuesta y Torre, arcediano de la Catedral de Avila y penitenciario de los Hospitales de la misma. Condenado por jansenista en 1801 por la Inquisición, escapó a Bayona, donde le dio cobijo el conde de Cabarrús. Luego, estudió ciencias naturales y economía política en París. De vuelta a España, en 1808 rechazó ser Consejero de Estado del rey José I, optó por el bando de los patriotas liberales y se trasladó a Cádiz. Hecho preso en 1814 por los absolutistas, luego fue elegido diputado a Cortes por Avila en 1820. El 23 de septiembre de 1823, llegó a Burdeos y, en noviembre de 1824 , se asentó en París, donde frecuentaba a la flor y nata política e intelectual del liberalismo moderado -en especial al conde de Toreno y a Martínez de la Rosa- y los policías de Luis XVIII reconocían que era un verdadero estadista, dotado de grandes talentos y conocimientos. Aunque enfermo, solicitó y obtuvo un visado para viajar a Londres en 1828, pero la muerte le alcanzó en el camino, en Calais ${ }^{34}$.

Por más que fuera todo un canónigo doctoral de Badajoz y director de los establecimientos de beneficiencia de la ciudad, Pedro Pérez Mendo, asilado en Burdeos, se vio en la penosa tesitura en mayo de 1831 , de tener que pedir una ayuda financiera, que le concedió el gobierno francés. Por haber predicado a favor de las libertades públicas, había sido destituido, despojado de sus prebendas y condenado, en 1823, a una pena de ocho años de reclusión en un monasterio. No atreviéndose a regresar a su patria después de la amnistía del 15 de octubre de 1832, por miedo a las autoridades eclesiásticas, sólo volvió en abril de 1834 , a raíz del indulto definitivo decretado por María Cristina ${ }^{35}$.

Más pronto pudo retornar a España Pedro González Vallejo, obispo de Mallorca desde septiembre de 1819, quien fue elegido diputado a Cortes por Soria y presidente de las mismas en 1820. Obligado a abandonar su mitra, en octubre de 1824 emigró, acompañado por dos sobrinos y un secretario, a Montpellier donde llevó una existencia muy tranquila, alternando con lo que el prefecto del departamento del Hérault llamaba "la buena sociedad", o sea notables de opiniones políticas por encima de toda sospecha.A mayor abundamiento, precisaba el prefecto que si bien el prelado se había mostrado muy favorable al sistema constitucional -lo que le obligó a alejarse de su

33. $\mathrm{F}^{7} 12089 \mathrm{n}^{\circ} 708$.

34. $\mathrm{F}^{7} 11984 \mathrm{n}^{\circ} 2$; véase también Gil Novales, A., Diccionario biográfico del Trienio liberal, (en adelante DBTL), Ediciones El Museo Universal, Madrid, 1991.

35. $\mathrm{F}^{7} 12079 \mathrm{n}^{\circ} 179$. 
país-, no se le podía reprochar haber participado en ningún exceso revolucionario. Hasta el propio rey Fernando había encomiado la moderación de sus discursos cuando ostentaba la presidencia de las Cortes $^{36}$. Esta ponderación también la sugiere el retrato que el agudo redactor de las Condiciones y semblanzas de los diputados a Cortes para la legislatura de 1820 y 1821 bosquejó del mitrado mallorquín:

"VALLEJO: Obispo ilustrado y docto, varón "vere" apostólico, caritativo sin vanidad, sabio con sencillez y piadoso sin gazmoñería. Alto, seco, decoroso y de amable presencia: sabe hablar bien y se contenta con votar y callar" ${ }^{37}$.

Es de creer que fue este moderantismo lo que le permitió cruzar el Pirineo, camino del regreso, en 1830.

Al contrario,Antonio Posada Rubín de Celis, abad mitrado de Villafranca del Bierzo, diputado por Murcia en 1820 y encumbrado a la mitra de Cartagena-Murcia en 1821 a iniciativa del gobierno liberal ${ }^{38}$, tuvo que permanecer en Francia hasta mayo de 1834. Miembro de una conocida familia de "jansenistas", o sea de católicos ilustrados, Posada debió a su acendrado liberalismo así como a su talante aperturista el estar encargado de regir la diócesis murciana, en un ambiente político muy tenso, por los enfrentamientos callejeros entre liberales y serviles ${ }^{39}$. Lo cual le mereció el ocurrente elogio del autor de las Condiciones...:

\section{"RUB IN:Descendit de coelis et sedet at dexteram Patris"}

En la Carta pastoral que publicó el prelado en 1822, condenó tajantemente el despotismo y defendió con entusiasmo la monarquía constitucional, sin dejar de asumir posturas moderadas. Pero, tachada de "furibundo manifiesto revolucionario" por los absolutistas, dicha pastoral les sirvió de máquina de guerra para obligarlo a renunciar en $1824^{41}$. En Aix-en-Provence, donde se instaló con su sobrino Joaquín en mayo de 1825, fue calurosamente acogido por el arzobispo y el cabildo, a quienes ayudó en las tareas de su ministerio. Según una nota del prefecto al ministerio del Interior, esto se debía a que, pese a haber sido promovido obispo bajo el régimen constitucional, no se podía poner en tela de juicio la pureza de su doctrina. Además, proseguía la nota, los revolucionarios españoles no habían atentado, de ninguna manera, contra las leyes de la Iglesia ni contra la constitución ortodoxa del clero, por ende existía una enorme diferencia entre los llamados obispos "constitucionales" franceses y un prelado español nombrado para una sede vacante entre 1820 y 1823 . Posada infundía, pues, tanta confianza a las autoridades de la Francia del intransigente Carlos X que le autorizaron

36. $\mathrm{F}^{7} 12045 \mathrm{n}^{\circ} 1386$.

37. Condiciones y semblanzas de los diputados a Cortes para la legislatura de 1820 y 1821 , Madrid, en la imprenta de Ramos y cpñía, 1821, p. 71.

38. Mas Galvañ, C. "Un foco de catolicismo liberal: el seminario de San Fulgencio de Murcia durante elTrienio liberal" en Libéralisme chrétien et catbolicisme libéral en Espagne,France et Italie dans la première moitié du XIX ${ }^{\circ}$ siècle, Université de Provence, 1989, p. 153.

39. Ibid., p. 153 sig.; véase también Higueruela del Pino, L., "El catolicismo liberal en don Antonio Posada, obispo de Murcia" en Libéralisme chrétien..., p. 361-398.

40. Condiciones..., p.18.

41. Mas Galvañ, C., art. cit., p. 153 sig. e Higueruela del Pino, L., art.cit.; véase también el texto de la Carta pastoral... publicado por Dufour, G., Sermones..., p. 167-184. 
en 1827 a viajar libremente por el país. No obstante, en 1829 , la policía de Perpiñán aportaba algunos matices y reparos: se barajaba la participación del prelado en una trama urdida entre los liberales de Barcelona y algunos de los refugiados en Francia. Todo hubo de quedar en meras sospechas pues, en adelante, no se informó más sobre el asunto ${ }^{42}$.

Podríamos multiplicar tales ejemplos que atestiguan la emigración a Francia de clérigos españoles de alto rango si no temiéramos cansar al lector -que podrá encontrarlos en la lista que publicamos al final de este trabajo-. No obstante, merece interés recalcar que de los 18 dignitarios eclesiásticos de cuyo exilio en tierras galas tenemos constancia, 11 se habian beneficiado de un ascenso durante el Trienio.Aparte del obispo Posada, entre las más relevantes promociones destacan la de Mariano José Sicilia, -ya prior electo de la Colegiata de Baza, en el obispado de Guadix, en 1819 y prior en funciones en 1820 , fue luego nombrado vicario general de su diócesis-, la de Juan Nicasio Gallego, -otrora diputado en las Cortes de Cádiz, y por más señas también poeta, que era ya todo un canónigo racionero de Cartagena desde 1809 y se vio gratificado con la dignidad de arcediano mayor de Valencia en 1820-, o la de Juan Ferrer, quien alcanzó los cargos de beneficiado y protonotario de Mallorca ${ }^{43}$. Para estos clérigos ascendidos durante el régimen constitucional, resulta pues obvio el alto grado de compromiso con la causa liberal.Y también lo es para otros dos sacerdotes emigrados que fueron diputados a Cortes en 1822.

Estrechamente vinculado al obispo Posada, Bonifacio Sotos Ochando, fue nombrado, durante el Trienio, rector del Seminario de San Fulgencio, importante foco de jansenismo y luego de catolicismo liberal en Murcia. Diputado por dicha ciudad, votó la momentánea destitución del rey Fernando y su sustitución por una regencia liberal el 11 de junio de 1823. Exiliado en Francia en 1825, fue más tarde preceptor de los hijos de Luis Felipe y dio a luz numerosos trabajos lingüísticos, redactados en español y en francés ${ }^{44}$.

Hecho canónigo de Baza en el período constitucional, Pedro Alvarez y Gutiérrez fue igualmente elegido diputado por Granada en 1822. Llegó a Marsella, procedente de Gibraltar, en julio de 1824, antes de trasladarse a Aix-en-Provence en agosto. Allí vivió tranquilo, dedicándose al estudio y acudiendo con asiduidad a las bibliotecas públicas. En mayo de 1827 , solicitó y obtuvo el permiso de viajar a Montsauche, cerca de Château-Chinon, en el centro de Francia, para dar las gracias al juez Charles Ruffy, ex capitán del $20^{\circ}$ regimiento de cazadores, quien le había salvado la vida en España (es éste uno de los muchos testimonios de que las tropas de Angulema protegieron a los liberales españoles contra el encarnizamiento de los serviles). Residiendo todavía en Aix en 1831, logró un subsidio de 2 francos diarios, ayuda de la que estaba muy necesitado, según el informe policíaco, pues había perdido todos sus bienes y estaba muy enfermo. Por haber votado la destitución de Fernando VII, quedó excluido de las sucesivas amnistías y sólo pudo regresar a su patria en 1834 , a los ochenta años ${ }^{45}$.

42. $F^{7} 12016 n^{\circ} 2171$ y $F^{7} 12028 n^{\circ} 847$.

43. Sánchez de Haedo, J. y Escartín, M. de, Guía del estado eclesiástico seglar y regular de España e Indias para el año de 1819, Imprenta de Sancha, Madrid, 1819, p. 231 y 107; Ibid., 1820, p. 112.

44. Ibid.; Mas Galvañ, C., art.cit., p.163; Gil Novales, A., DBTL.

45. Sánchez de Haedo, J. y Escartín M. de, op. cit.; $F^{7} 12036$ n 1048 y F 12023 n $^{\circ} 658$. 
No cabe duda de que, como los demás mascarones de proa del liberalismo cristiano, estos eclesiásticos que asumieron comprometerse a plena luz obedecían a poderosas motivaciones ideológicas. Como han analizado distintos historiadores, los clérigos que apoyaron el nuevo régimen a ciencia y conciencia, eran herederos de los "jansenistas" dieciochescos y de éstos recogieron las tesis regalistas y episcopalistas. Aspiraban a la formación de una Iglesia nacional, independiente de Roma, regida por los obispos españoles en lo espiritual y sometida al poder regio en lo temporal. Pero, a diferencia de su abuelo Carlos III, celoso defensor de sus regalías frente a las intromisiones de Roma y de la Inquisición, Fernando VII, quien se había restablecido como rey absoluto en 1814 gracias a la renovada alianza del Trono y del Altar, había renunciado al regalismo y cumplía a rajatabla los dictados del papado en cuestiones religiosas. Para combatir este ultramontanismo, los eclesiásticos "jansenistas" respaldaron la labor de las Cortes, de las que ya sólo podían esperar la ansiada reforma de la Iglesia. Por ende antepusieron al servicio del Rey el servicio a la Nación, lo que era en sí un acto revolucionario ${ }^{46}$.

Sin embargo, no todos los sacerdotes luego acusados de adhesión al régimen constitucional tenían tan sólidas convicciones. Hubo quienes aceptaron la revolución de 1820 como un hecho consumado y, adaptandose a las circunstancias, obedecieron pasivamente a las autoridades civiles. Por cierto, en los primeros meses, la mayoría del clero español no se mostró francamente hostil al restablecimiento de la constitución. Incluso, algunos prelados redactaron pastorales en loor del nuevo sistema, cumpliendo así, sin hacerse de rogar, la Real Orden del 12 de abril de 1820, en que el gobierno liberal, conocedor del influjo del púlpito en la mentalidad del pueblo, mandó que los eclesiásticos hicieran propaganda por la constitución y explicaran a los fieles la compatibilidad de la Carta Magna con la religión ${ }^{47}$. Pero, a partir de octubre de 1820, cuando la inmensa mayoría del clero se movilizó en contra de la reforma de las órdenes religiosas, los clérigos difícilmente podían evitar decantarse nítidamente por uno u otro campo.

A pesar de todo, era lo que alegaba Mariano Sicilia, canónigo dignidad y prior de la iglesia colegial de Baza, en una carta que dirigía en junio de 1825 al ministro del Interior pidiendo ser autorizado a marcharse de Aix-en-Provence para Villebon, de cuya parroquia acababa de encargarle el obispo de Versalles. Según afirmaba, no había tomado parte alguna en la revolución de España, ni había sido promovido a cargo alguno por el gobierno "sedicente" constitucional. Durante esa triste época, sólo se había atenido a observar las reglas más estrictas de la obediencia pasiva, como vicario general que era de su diócesis. Pero, disfrutaba de una de las más ricas prebendas de España y fue injustamente denunciado por "personas" que codiciaban ocupar su cargo. Por eso en 1823, se fue a buscar paz y asilo bajo el "suave y apacible" gobierno de Francia. En agosto de 1825, el ministro de Asuntos Eclesiásticos corroboraba las afirmaciones de Sicilia, confirmando que era de todo punto tranquilo y fidedigno. Tan sólo facilitaba a su colega del Interior explicaciones más detalladas sobre las circunstancias en que el canónigo había llegado a Francia. Entró en calidad de capellán, incluido en la capitulación de Cartagena. En realidad, fue durante la guerra de la Independencia

46. véase en particular La Parra López, E., op. cit.; Dufour, G.,Juan Antonio LLorente..

47. Revuelta González, M., op. cit., p. 121 sig. 
cuando había sido capellán de un regimiento que combatía contra "Buonaparte" -con la ortografía que solía utilizar despectivamente la administración de la monarquía de la Restauración para referirse al "Usurpador"-, y si el mando militar francés lo registró como capellán en 1823 fue únicamente para que cobrara los subsidios prometidos en el documento de rendición ${ }^{48}$. No se arredraba pues Sicilia por mentir descaradamente: en primer lugar, porque fue durante el régimen de las Cortes cuando se benefició del ascenso a vicario general de su diócesis y, en segundo lugar, porque luego, ya instalado en París en 1831, no vaciló, para conseguir una ayuda económica, en hacer alarde de haber sido capellán del ejército constitucional durante el Trienio ${ }^{49}$. Por supuesto, se trataba, esta vez, de seducir al gobierno liberal de Luis Felipe... Era sin duda el canónigo andaluz un redomado hipócrita o, cuando menos, un avispado maniobrista y, a buen seguro, poco amigo de compromisos firmes. Pero aparece más bien como un caso aislado entre los sacerdotes españoles refugiados en Francia a partir de 1823.

Efectivamente, al lado de unos pocos expedientes de clérigos españoles asilados en los que no consta ningún dato sobre la actitud adoptada durante el Trienio, en la mayoría de los casos la policía francesa apuntó observaciones que dejan suponer la sincera adhesión de los eclesiásticos emigrados a las ideas liberales. Huelga decir que estas informaciones se han de utilizar con cautela y matizar: la administración francesa obviamente juzgaba con arreglo a sus propios criterios. Así, la policía de Luis XVIII recalcó que 7 presbíteros habían predicado a favor de la constitución, lo que valoraba, a todas luces, como un acto grave e inequívocamente revolucionario. Ahora bien, resulta precisamente bastante difícil deslindar qué grado de compromiso podía significar semejante predicación. Ya hemos dicho que la jerarquía religiosa española no optó de entrada por la beligerancia contra el nuevo sistema. Los prelados se dignaron jurar la constitución, aunque algunos lo hicieran a regañadientes ${ }^{50}$. Y tras la referida orden cursada a los obispos el 12 de abril de 1820, el que un sacerdote elogiara la Carta Magna en sus sermones no pasaba de ser mero cumplimiento de los mandamientos de su jerarquía. Por supuesto, la Curia Romana pronto puso en entredicho la constitución española, en especial porque establecía la libertad de imprenta ${ }^{51}$, o sea la libertad de difundir ideas innovadoras que amenazaban el control ejercido por la Iglesia en las mentalidades. Mas, según que el prelado de su diócesis ostentara una actitud de prudencia o hasta en algunos casos de franca simpatía por el liberalismo, no todos los clérigos hubieron de estar enterados de este anatema. Recordemos que todavía en agosto de 1822, el mitrado de Cartagena-Murcia,Antonio Posada Rubín de Celis incitaba ardorosamente a sus subordinados a exponer a los fieles la bondad del sistema liberal. Mediaba pues, gran trecho entre el párroco que predicaba a favor la constitución lisa y llanamente por cumplir y un cura como el de Bustaviejo, en la diócesis de Toledo, quien mandaba cerrar las puertas de su iglesia para que ninguno de sus feligreses escapara de oirle encomiar la constitución ${ }^{52}$. Sin embargo, y aunque no llegaran a dar tan rotundas muestras de entusiamo, es de creer que si unos eclesiásticos aban-

48. $\mathrm{F}^{\top} 12023 \mathrm{n}^{\circ} 658$.

49. Sánchez de Haedo, J. y Escartín, M. de, op. cit., 1819, p. 230-231; ibid., 1820, p. 239. 241; F 12084 $\mathrm{n}^{\circ} 408$.

50. Revuelta González, M., op.cit., p.123.

51. Dufour, G., Sermones..., p. 7.

52. Ibid., p. 38. 
donaron su patria sintiéndose en peligro por haber predicado en pro del nuevo sistema, lo habrian hecho con marcada convicción.

Sin lugar a dudas fueron tan sinceramente convencidos, pero obviamente menos afortunados, los sacerdotes quienes sólo pudieron refugiarse en Francia después de verse sometidos a castigos impuestos por el gobierno absolutista $y$, sobre todo por la jerarquía religiosa servil. Por ejemplo, Juan José de Aguirre Bengoa, canónigo de la Catedral de Cuenca, nombrado durante el Trienio vicario general castrense de las provincias de Chinchilla, Cuenca y Guadalajara, llegó a Bayona en abril de 1831 pidiendo el amparo de Luis Felipe, tras haber escapado de un calabozo donde expiaba su devoción a las instituciones que, según confiaba, habrían elevado su patria a la categoría de nación libre y feliz. Por mucho que dicha evasión parezca a primera vista algo fantástica y deje sospechar que Aguirre, privado de sus prebendas, procurara ante todo cobrar una ayuda económica, en realidad, las pesquisas efectuadas por la policía francesa confirmaron en julio de 1832, que el canónigo había sido sentenciado por los tribunales de Su Majestad Católica a cadena perpetua por motivos políticos -desgraciademente no sabemos en qué había incurrido para merecer semejante castigo-, y que lógicamente no podía volver a España sin correr el peligro de dar con sus huesos en una mazmorra ${ }^{53}$. Por su parte, José María de Alcocer, cura párroco de Santa Cecilia de Medellín, en la diócesis de Plasencia, tuvo que vérselas con el encarnizamiento de su jerarquía: según la policía de Bayona, a donde emigró en octubre de 1829, era uno de los más fogosos predicadores de la causa constitucional en Extremadura. Por consiguiente, después del Trienio, su conducta fue sometida a examen por la justicia de Fernando VII, pero el proceso no desembocó en ningún castigo. En cambio, la jurisdicción eclesiástica se mostró menos indulgente -así lo subrayaba la policía del intransigente Carlos $\mathrm{X}-, \mathrm{y}$ lo mandó recluir en un convento ${ }^{54}$. Otro caso similar lo constituye el de Francisco de Borja Fernández quien, ya antes de 1820 era canónigo magistral de la Colegiata de Briviesca, cerca de Burgos, y huyó a Bayona en septiembre de 1831, a sus sesenta y ocho años, tras permanecer cinco incomunicado en un monasterio. Su crimen, confesaba, consistía en haber manifestado simpatía por la libertad y la gloria de su patria cada vez que podía compaginar sus deberes de ciudadano español con la santidad de su ministerio evangélico ${ }^{55}$.

Más abiertamente comprometidos, si cabe, fueron los clérigos quienes no dudaron en ejercer el sacerdocio al servicio de los soldados que defendían el régimen liberal y recordemos que 43 de los eclesiásticos asilados en Francia eran capellanes de las tropas constitucionales. Por supuesto, no se puede descartar que conseguir una capellanía militar fuera para algunos de los frailes secularizados una tabla de salvación a la hora de encontrar una "recolocación" mientras la jerarquía religiosa se mostraba más bien proclive a negarles el pan y la sal a los exclaustrados. Pero, en el caso concreto de los 8 ex monjes metidos a capellanes militares que luego se exiliaron a Francia, nada permite sospechar que ingresaran en el ejército constitucional tan sólo por afán de asegurar su sustento. Antes al contrario, un sacerdote quien libremente escogía luchar tan notoriamente en las filas liberales, exponiéndose a ser canónicamente ful-

53. $\mathrm{F}^{7} 12081 \mathrm{n}^{\circ} 263$.

54. $\mathrm{F}^{7} 12072 \mathrm{n}^{\circ} 2753$.

55. $\mathrm{F}^{7} 12081 \mathrm{n}^{\circ} 262$. 
minado por la Iglesia, daba innegables pruebas de su auténtica adhesión al régimen de las Cortes. A mayor abundamiento, entre los capellanes militares emigrados a Francia destacan unos de los más activos revolucionarios. De ello es un buen exponente Miguel de la Peña y Oliva, nombrado durante el sistema liberal cura de San Roque, cerca de Gibraltar, quien llegó al país galo en septiembre de 1831, al cabo de una vivencia y de un recorrido tormentosos. Siendo capellán de un regimiento liberal en 1823, se refugió primero en Inglaterra antes de trasladarse a Portugal en 1827. Encarcelado cuando la entronización de dom Miguel, sólo recobró la libertad dos años más tarde, en 1830. Pasó entonces a Gibraltar y fue enviado por los ingleses a Argel, de donde embarcó con rumbo a Marsella. Falto de cualquier recurso, vivió en el depósito de refugiados de Tours, gracias al subsidio que le asignó el gobierno de Luis Felipe. Subsidio que se le mantuvo hasta 1834 , pues estaba tan gravemente comprometido que no podía arriesgarse a regresar a España antes de que los liberales estuvieran total y definitivamente amnistiados: como jefe de una partida de guerrilleros, había participado en la tentativa insurreccional liberal conducida por el coronel Francisco Valdés en Tarifa, en agosto de $1824^{56}$.

Aunque sin ser capellanes militares, otros de los eclesiásticos emigrados a Francia tampoco se arredraron por empuñar las armas. En 1820, en las cercanías de Teruel, el presbítero Joaquín Royo, encabezó un ataque de los moradores de su pueblo contra unos ciento diez serviles alzados contra el sistema constitucional. Esta hazaña le costó dos años de encarcelamiento, tras el restablecimineto de Fernando VII como "rey neto". En septiembre de 1831, siendo todavía víctima de vejaciones y persecuciones, cruzó la frontera para buscar cobijo en Bayona ${ }^{57}$. Del mismo modo, el religioso hospitalario de la orden de San Juan de Dios, José Parnau, natural de Manresa y director del hospital de Nuestra Señora del Buen Socorro en La Coruña, tomó parte activa, al frente de un grupo armado, en la expedición de Vera que Espoz y Mina, alentado por el triunfo de la revolución de Julio en Francia, organizó en octubre de 1830, con vistas a acabar con el absolutismo en España. Luego residió Parnau en Montpellier, recibiendo de las autoridades francesas una ayuda diaria de 1,50 franco, hasta que la amnistía del 23 de octubre de 1833 le permitiera volver sin miedo a su patria ${ }^{58}$.

Ya hemos recalcado cuanto la policía de la Francia de la Restauración desconfiaba de los extranjeros refugiados. Pero, hay que reconocer que si en muchas ocasiones manifestaba un celo excesivo, no obstante algunos de los asilados a quienes consideraba como sujetos particularmente peligrosos efectivamente bien podían llamar su atención.Así, el fraile exclaustrado Gabriel Arrambide -que ya en 1815 vivía en Bayona desde donde enviaba a España propaganda revolucionaria y regresó a Pamplona en $1820^{59}$-, fue detenido en Francia por espía en 1822, mientras intentaba reclutar agentes que colaborasen con Juan Olavarría, uno de los principales jefes revolucionarios. Expulsado en enero de 1823, Arrambide volvió en noviembre a esconderse en Bayona, tras escapar de la cárcel de Tolosa, en Guipúzcoa, donde estaba recluido como criminal de Estado. Hecho preso de nuevo por los sabuesos bayoneses, quienes le incauta-

56. $F^{7} 12090 n^{\circ} 835$.

57. $F^{7} 12087 n^{\circ} 620$.

58. $\mathrm{F}^{7} 12090 \mathrm{n}^{\circ} 811$.

59. Gil Novales,A., DBTL. 
ron un texto cifrado, fue puesto en libertad por el Tribunal de Primera Instancia de la ciudad y enviado a Agen. Tachado de revolucionario exaltado y peligroso, fue objeto de una muy estricta vigilancia, pero no dio nada que decir. Ahora bien, negándole el obispo la licencia de rezar misa, estaba sumido en la miseria y por eso, porque no tenía con que mantenerse, en octubre de 1824 se le mandó salir de Francia, lo que hizo en marzo de 1826, marchándose con destino a Bruselas, tras haber intentado en vano embarcarse para Lisboa ${ }^{60}$.

En cuanto al riojano Francisco Martín Merino, la policía también tenía fundados motivos para recelar de él y seguirle los pasos cuidadosamente. Este franciscano secularizado, nacido en Arnedo, ya perseguido por su adhesión al liberalismo y asilado en Francia en 1819, había regresado a España en 1820, gracias a la revolución ${ }^{61}$. Parece que defendió el régimen constitucional en los enfrentamientos callejeros del 7 de julio de 1822 en Madrid y que por eso estuvo encarcelado en 1823. Buscó otra vez cobijo en Bayona en diciembre de 1824, afirmando temer el restablecimiento de la Inquisición en su país. En Agen y luego en Laidental, cerca de Burdeos, donde consiguió ser nombrado teniente de cura, llevó una vida tranquila hasta el punto de obtener el permiso de residencia en julio de $1827^{62}$. Con todo, no hubo de cejar en sus ideas revolucionarias dado que, a los sesenta y tres años de edad, intentaría matar a la reina Isabel II el 2 de febrero de 1852, por lo que sería ajusticiado en Madrid cinco días más tarde ${ }^{63}$.

Otro de los sacerdotes liberales españoles tildado de revolucionario furibundo y peligroso por los funcionarios del ministerio francés del Interior era Lorenzo Feijoo, ex director de un centro docente. En Courbiac, cerca de Agen, donde residía, se le reprochaba proferir discursos subversivos y mantener una activa correspondencia con España.Además, se sospechaba que pertenecía a varias sociedades secretas y, especialmente a una logia masónica ${ }^{64}$. En el caso concreto de Feijoo, no hemos podido comprobar la veracidad de esta acusasión que obviamente constituía, a ojos de las autoridades francesas, un terrible agravante. Mas, gracias a las listas de masones eclesiásticos españoles levantadas por Vicente Cárcel Orti y por José Antonio Ferrer Benimeli $^{65}$, podemos afirmar a ciencia cierta que 12 de los clérigos exiliados en Francia a partir de 1823 se habían afiliado a una sociedad secreta.

Entre estos eclesiásticos masones, dos atravesaron por momentos particularmente sombríos y críticos. Antonio Barragán, natural de Arnedo, ex fraile agonizante y capellán de la "Columna Patriótica", el primer batallón de la milicia nacional de Zaragoza, fue un fervoroso predicador de la constitución. Más tarde fue capellán del $9^{\circ}$ regimiento de Infantería que capituló en Huesca y sólo llegó a Bayona en enero de 1825 , tras superar grandes dificultades. Por considerarlo un enconado constitucional, de

60. F’ $11999 \mathrm{n}^{\circ} 224$ y $\mathrm{F}^{\prime} 12051 \mathrm{n}^{\circ} 1699$.

61. Gil Novales, A., DBTL.

62. Ibid.; véase también $\mathrm{F}^{7} 12050 \mathrm{n}^{\circ} 1623$ y Bulletin des Lois du Royaume de France, $8^{\circ}$ série, 1827, Tome VII, p. 36.

63. Gil Novales A., DBTL.

64. F711989; véase también Gil Novales,A., lbid.

65. Cárcel Orti, V., art.cit., p. 269-277; Ferrer Benimeli, J.A., Masonería, Iglesia e Ilustración, Tomo IV: La otra cara del conflicto, conclusiones y bibliografía, Fundación Universitaria Española, Madrid, 1977 , p. 227-233. 
principios políticos pésimos, el obispo de Dax no le concedió licencia para decir misa. Falto de cualquier recurso, no estuvo autorizado a permanecer en Francia y en abril de 1825 optó por emigrar a Inglaterra ${ }^{66}$. Allí se hizo pastor protestante y se casó, pero su mujer murió de parto. A continuación, sobrevivió dedicándose a fabricar chocolate $^{67}$. En cuanto a Domingo Bondía, nacido en Maella (Aragón), religioso exclaustrado, capellán del ejército de Ballesteros y masón espontaneado, huyó de las persecuciones a las que estaba sometido en España, emigrando a Bagnères-de-Bigorre en febrero de 1824. Desde dicembre de 1825, vivió discretamente en Auch, pero provocó gran revuelo -muy a pesar suyo-, intentando suicidarse en diciembre de 1829 , a los cincuenta y un años. A consecuencia de tamaño escándalo, tuvo que trasladarse a Burdeos, donde se le asignó 1,50 franco al día a partir de marzo de 1832, dado que había agotado sus propios recursos y que, todavía incapaz de hablar el francés al cabo de ocho años de residencia, no podía desenvolverse ejerciendo su ministerio ${ }^{68}$.

Algunos de los clérigos masones refugiados a Francia descollaban por su alto nivel de preparación intelectual y por los cargos que desempeñaron. Así Salvador López, oriundo de Málaga, ya canónigo de Berlanga (diócesis de Sigüenza) antes de 1820, fue durante el Trienio profesor de derecho natural y constitucional en la Universidad de Sevilla. Perseguido por su actitud política y despojado de su canonjía en 1823, conoció días apacibles en Montpellier, si bien padecía estrecheces y tuvo que solicitar un subsidio en octubre de 1831 . Gracias tanto a su notoria moralidad y buena conducta como a sus opiniones verdaderamente cristianas -según el prefecto del departamento del Hérault-, se granjeó simpatías en Montpellier, donde permaneció hasta febrero de $1834^{69}$. Por su parte, Martín Rentero, quien obtuvo un curato en una parroquia de Murcia durante el régimen de las Cortes, y a la vez desempeñó los cargos de archivero de la Diputación Provincial y de secretario de la Sociedad Patriótica murciana, salió para Francia bajo la protección de las tropas de Angulema por acogerse al convenio de capitulación de Cartagena. En 1828, se asentó en Lyon donde subsistía diciendo misa diaria y celebrando algún que otro entierro en la parroquia de Saint-Pierre.A partir de diciembre de 1830, benefició de un subsidio de 45 francos mensuales hasta que pudiera volver a su patria, en marzo de $1834^{70}$. El también masón José María Moralejo ${ }^{71}$ recibió la misma ayuda económica después de febrero de 1832 . Este presbítero, cura propio de San Juan de Brihuega, en el arzobispado de Toledo, era doctor en teología por la Universidad de Alcalá de Henares y autor de distintos planes muy radicales de reforma del clero español ${ }^{72}$. Se asiló en Inglaterra en 1823 tras sufrir, según afirmaba, una tentativa de asesinato por parte de los apostólicos. En enero de 1830 , con sesenta años cumplidos, desembarcó en Lila en busca de un clima más suave y sin duda también atraído por la perpesctiva de cobrar un subsidio. Llevando una vida retirada y dando clases de idiomas, se asentó en mayo de 1832 en París, donde publicó en 1835 un Manuel de conversations françaises et espagnoles, de 338 páginas en $12^{\circ}$, en la

66. $\mathrm{F}^{7} 12050 \mathrm{n}^{\circ}$ 1663; Cárcel Orti., art.cit., p. 269.

67. Gil Novales, A., DBTL.

68. Cárcel Orti, V., art. cit., p. 274 y F $12028 \mathrm{n}^{\circ} 840$.

69. $\mathrm{F}^{7} 12084 \mathrm{n}^{\circ}$ 420; Ferrer Benimeli, J.A., op. cit., p. 230.

70. Gil Novales,A., DBTL; Cárcel Orti V., art.cit., p. 273; F 12090 n $^{\circ} 812$.

71. Ferrer Benimeli, J. A., op. cit., p. 230.

72. Revuelta González, M.,op. cit., p. 93 y 98. 
imprenta de Casimir ${ }^{73}$. Ya en Barcelona en 1838, fue profesor en el Instituto de Sordomudos, antes de alcanzar una cátedra en la Universidad de Madrid en $1844^{74}$.

Afiliados a la Comunería, sociedad secreta creada en enero de 1821 por el sector más radical del liberalismo español, eran 3 de los clérigos exiliados en Francia. El presbítero Joaquín Saez de Quintanilla, catedrático de derecho canónico y nombrado rector de la Universidad de Valencia por el gobierno constitucional, fue víctima de encarnizadas persecuciones en 1823, por lo cual se refugió en Aix-en-Provence en 1824. Sobrevivió primero gracias a sus recursos personales, pero en septiembre de 1832, pidió y obtuvo 1,50 franco como subsidio diario ${ }^{75}$. En lo que atañe a Antonio Cebrián, natural de Córdoba, ya había combatido en el bando patriótico contra Napoleón y fue capellán del $2^{\circ}$ regimiento de Artillería de la Guardia Real durante el Trienio liberal. Al retirarse de Barcelona el ejército francés, de cuya protección disfrutaba, Cebrián se marchó en agosto de 1826 para Perpiñán, donde vivió apaciblemente, siendo autorizado por el obispo a decir misa en la parroquia de la Real. En 1829, residía en París, donde era sacerdote adscrito en la iglesia Notre-Dame-des-Victoires, antes de volver a Perpiñán para cruzar la frontera en junio de $1833^{76}$. Comunero también era Juan José Aguirre Bengoa, canónigo de Cuenca y vicario general castrense de Chinchilla, Cuenca y Guadalajara, a quien ya nos hemos referido ${ }^{77}$.

Sobrados motivos tenían estos masones y comuneros para abandonar su patria pues, además de las medidas represivas ya dictadas en 1823 contra los liberales, Fernando VII expidió el 6 de febrero de 1824 un decreto mandando separar de sus prebendas y beneficios a los eclesiásticos que hubieran sido miembros de una sociedad secreta ${ }^{78}$. Y por si fuera poco, al mes siguiente, otra Real Orden agravó las represalias exhortando a los prelados a imponerles castigos canónicos y hasta penas de reclusión en monasterios ${ }^{79}$. Ni siquiera pudieron gozar de más clemencia los clérigos masones espontaneados, o sea aquéllos que abjuraron de la "secta" a la que habían pertenecido. De hecho, eran perdonados pero el indulto no significaba el reintegro a las prebendas o a los curatos de que anteriormente disfrutaran, y se les mandaba aplicar los mismos castigos ${ }^{80}$. Por otra parte, excusado es decir que quienes pertenecían a una sociedad secreta quedaron excluidos de la amnistía otorgada por el monarca el $1^{\circ}$ de mayo de $1824^{81}$.

No faltó entre los eclesiásticos masones españoles quien jugó con dos barajas: el ex mercedario pamplonés y lector de teología Juan Mata de Echeverría, a pesar de todo un currículo de revolucionario muy activo, luego pretendió haber colaborado con los liberales únicamente como agente secreto al servicio del monarca español.Y en realidad parece que, si bien era miembro activo de la Sociedad Patriótica de Pamplona, masón, espía y conspirador estrechamente vinculado al jefe liberal Juan

\footnotetext{
73. $\mathrm{F}^{7} 12081 \mathrm{n}^{\circ} 298$.

74. Gil Novales, A., DBTL.

75. Ferrer Benimeli J. A.,op. cit., p. 231 y F 12092 n $^{\circ} 940$.

76. Ibid., p. 228 y F $^{7} 12071 \mathrm{n}^{\circ} 2684$.

77. Ibid., p. 227; véase supra p.267.

78. citado por Dufour, G., Sermones..., p. 44.

79. Ibid.

80. Cárcel Orti, V., art. cit., p. 266.

81. Historia de la vida y reinado de Fernando VII...., p. 448.
} 
Olavarría, al mismo tiempo tenía puerta abierta en la "camarilla" real, en especial ante el muy influyente e intrigante secretario particular de Fernando VII, Antonio Ugarte, encargado por el rey de levantar bajo cuerda partidas absolutistas. En 1824 Mata emigró a Francia, afirmando ser perseguido por motivos políticos, lo que luego confirmó un informe del superintendente general de Policía español, Mariano Rufino González quien lo consideraba como un enconado revolucionario, digno de ser tratado con la mayor prevención. Lo cual no obstó para que Mata ofreciera trabajar por el ministerio francés del Interior e intentara "vender" a Franchet d'Esperey, el director general de la Policía, unas revelaciones acerca de acontecimientos que ya se habían producido durante el Trienio constitucional y unas supuestas conspiraciones urdidas entre liberales españoles y franceses para derrocar a los Borbones, tanto en España como en Francia. Las autoridades francesas no se dejaron embaucar y, tras sortear diferentes órdenes de expulsión, Mata tuvo que marcharse definitivamente, embarcando en Le Hâvre rumbo a Puerto Príncipe en abril de 1830. Desde luego, cuesta trabajo sacar en limpio si fue efectivamente un agente doble de los serviles o si, como parece más probable, fue un agitador revolucionario, quien ya exiliado y sumido en la miseria, procuró buscarse la vida como confidente de la policía francesa ${ }^{82}$. De todos modos, lo cierto es que al ex fraile de la Merced no le molestaba nadar entre dos aguas y que no brillaba por el rigor moral, al contrario de la mayoría de sus hermanos en religión, quienes supieron aguantar los penosos años de destierro con decoro.

No puede extrañar que los más de los clérigos liberales españoles asilados en Francia a partir de 1823 vivieran en el Suroeste del país, no lejos de la frontera española: así lo hicieron 92 de ellos, o sea casi el 71\%. Por supuesto, cuando la liquidación del régimen constitucional y la consiguiente llegada de los refugiados, las autoridades galas, preocupadas por impedir la organización de cualquier tentativa de restaurar el liberalismo en España, se cuidaron mucho de evitar que los emigrados se agruparan en los alrededores de la frontera y en los puertos del sur. De la misma forma, los ya aludidos depósitos establecidos para albergar a los prisioneros de guerra, lo estuvieron dentro de una zona que abarcaba desde el noroeste hasta el sudeste de Francia, procurando mantener una razonable distancia de seguridad con el Pirineo. Esto explica, que tras la disolución de dichos depósitos en mayo de 1824, algunos de los ex capellanes militares se hayan quedado en -o cerca de- los lugares donde estaban asentados: por ejemplo 6 en Laval, 5 en Alençon (noroeste), 6 en Bourges (centro), por muy lejos de su patria que se hallaran. Pero, esta circunstancia también permitió que permanecieran no pocos eclesiásticos españoles en sitios de clima más agradable y más próximos a su país como Périgueux, Nîmes o Aix-en-Provence, ciudades en las que también se habían constituido depósitos. Sin embargo, la concentración de sacerdotes refugiados en el departamento de Bouches-du-Rhône (8 en Marsella y 11 en Aix) a buen seguro habrá de relacionarse además con la protección que podía ofrecerles el obispo Posada Rubín de Celis, residente en Aix, y con la benévola actitud del prelado de la diócesis con quien aquél supo congraciarse.

82. Vauchelle, A., "Un eclesiástico entre liberalismo y absolutismo: Juan Mata de Echeverría" en Trienio, Ilustración y liberalismo, $n^{\circ} 27$, mayo de 1996, Madrid, p. 73-82. 
Por otra parte, si bien admitían en el reino la presencia de emigrados liberales, las autoridades de la Francia de la Restauración, obviamente eran poco propensas a facilitar recursos a unos posibles subversivos. Por eso, en un principio, habían sentado como norma que tan sólo estarían autorizados a permanecer en el país quienes estuvieran provistos de medios de existencia suficientes. Era pues, para todos los refugiados un problema de primera magnitud conseguir recursos económicos. De ahí que, ya suprimidos los depósitos y antes de que el gobierno francés concediera ayudas a los asilados, muchos de ellos procuraran trasladarse hacia grandes centros donde existían mayores oportunidades de ganarse con qué vivir. Ese acuciante afán lo compartían los eclesiásticos con los refugiados seglares y, lógicamente una gran ciudad les deparaba a ellos más posibilidades de encontrar algunas misas que decir o de verse agregados al clero de una parroquia e incluso, para los más cultos, de dar alguna que otra clase. Tales perspectivas constituyeron sin duda poderosos atractivos para los 17 sacerdotes españoles residentes en Burdeos, -por aquel entonces verdadera capital del exilio español-, y para los 15 asentados en París, urbes donde, por añadidura, la presencia de numerosos compatriotas suscitaba esperanzas de poder contar con cierta solidaridad.

Así, por ejemplo, el clérigo José Francisco Fuentes, asilado en Tolosa, logró del ministerio del Interior, en septiembre de 1829, el permiso de instalarse en París donde pudo alternar con Martínez de la Rosa y con el librero Hector Bossange, importante editor de obras impresas en castellano ${ }^{83}$. Y, gracias al auxilio económico del otrora afrancesado Alejandro Aguado, banquero en París, formó el proyecto de poner una tienda de productos españoles: vinos de Alicante y de Málaga, naranjas, granadas $\operatorname{etc}^{84} \ldots$ Distando mucho de tener el ímpetu mercantil de Fuentes, el ex canónigo doctoral y prior de la Colegiata de Baza, Mariano José Sicilia, quien se fue de Aix a Versalles en junio de 1825 y más tarde a París, sacó provecho de su pluma. Según la policía, pasaba la vida estudiando, encerrado en su gabinete y a esto había de incitarle su "monstruosa" obesidad, que apenas le permitía moverse ${ }^{85}$. Esta asidua dedicación le proporcionaba con qué redondear la modesta cantidad que cobraba como teniente de cura en Villebon (diócesis de Versalles). En efecto, además de realizar traducciones, compuso distintos manuales de gramática, en especial, unas Lecciones elementales de ortología y prosodia cuyos cuatro tomos fueron publicados en 1827 y 1828 por la imprenta de David y puestos en venta en nada menos de 3.000 ejemplares en la librería americana, es decir con vistas a despacharse en América latina ${ }^{86}$. Esto no impidió que, en septiembre de 1831, Sicilia solicitara -y obtuviera- un subsidio de 2,00 francos diarios alegando que la suspensión del tráfico comercial de los libreros franceses con América lo dejaba en apuros, tesitura tanto más grave cuanto que tenía que mantener a un sobrino suyo Narciso Antonio Fernández, también refugiado por haber pertenecido a la Milicia Nacional ${ }^{87}$.

83. Vauchelle A.,Les Ouvrages en langue espagnole publiés en France entre 1814 et 1833, Université de Provence, 1985, p. 61.

84. $\mathrm{F}^{7} 12072 \mathrm{n}^{\circ} \cdot 2742$.

85. $\mathrm{F}^{7} 12023 \mathrm{n}^{\circ} 658$.

86. Vauchelle,A., Les Ouvrages..., p. 190 y 198.

87. $\mathrm{F}^{7} 12023 \mathrm{n}^{\circ} 658$. 
Podríamos mencionar otros casos de eclesiásticos españoles asilados que pudieron valerse de sus dotes intelectuales y de sus conocimientos, pero los más numerosos, quienes tampoco disfrutaban de las influyentes amistades de José Francisco Fuentes, no tuvieron más remedio que procurar subsistir ejerciendo su ministerio. Lo cual requería superar una doble dificultad: congraciarse en primer lugar con los dignitarios, mayoritariamente reaccionarios, de la Iglesia de la Restauración y, después, recibir el beneplácito de las autoridades civiles. De hecho, seguía vigente la ley del 18 de Germinal del año X (8 de abril de 1802) que estipulaba que ningún extranjero podía ejercer funciones sacerdotales sin la autorización del gobierno ${ }^{88}$.

Así, los eclesiásticos españoles bien considerados tuvieron la oportunidad de paliar el déficit numérico del clero francés, diezmado a consecuencia de la Revolución. Efectivamente, de una proporción de 30 curas por 10.000 habitantes en 1790 , el clero parroquial se había reducido a 11 por 10.000 en vísperas de la Restauración ${ }^{89}$.Algunos sacerdotes españoles pudieron pues, por lo menos en los primeros años del destierro, llenar un hueco. Pero hacia 1830, conforme fueron surtiendo efecto los constantes esfuerzos por encuadrar a los fieles con pastores franceses numerosos y bien preparados $^{90}$, lógicamente mermaron para los españoles las posibilidades de vivir gracias a su ministerio evangélico: lo lamentaba Juan Espinal en 1831, viéndose privado, a causa de la competencia del clero francés, de los recursos que le había proporcionado el ejercicio del sacerdocio desde su llegada a Marsella, seis años antes ${ }^{91}$.

Tan sólo 21 de los eclesiásticos españoles emigrados fueron bastante afortunados para estar autorizados a ser tenientes de cura en una parroquia, previo nombramiento por el prelado de la diócesis. Las parroquias de las que fueron encargados estos sacerdotes extranjeros solían ser rurales y de poca importancia. En la jerarquía del clero parroquial, el cura párroco regía la principal parroquia del cantón -o del distrito en las grandes ciudades- y el teniente atendía una parroquia menor, también llamada "filial". En París, por ejemplo, a los doce distritos entonces existentes correspondían doce curatos y veintisiete filiales ${ }^{92}$. Conforme el concordato de 1801 , el clero francés era remunerado por el Estado, y cuando en 1827 un párroco, también llamado cura cantonal o deán, cobraba 1.500 francos anuales -cantidad que en las parroquias ricas llegaba a duplicarse gracias al pie de altar-, un teniente de cura tenía que contentarse con un corto sueldo de 750 francos, sin apenas poder contar con otros emolumentos, siendo generalmente modestas sus parroquias ${ }^{93}$. Pero no era la situación económica la única diferencia: el teniente de cura, a pesar de cumplir los mismos deberes y de tener las mismas responsabilidades, no gozaba de la inamovibilidad correspondiente al curato y ejercía su ministerio bajo la dirección y la vigilancia del párroco ${ }^{94}$. O sea que, poco retribuidos y siempre a la merced de la animadversión del cura o de un repentino cambio de actitud del prelado, los tenientes constituían los sol-

88. A.N.F., $F^{t 9}$ Police des Cultes. Empire et Restauration, legajo 5695.

89. Lebrun, F, op. cit., p. 330.

90. Ibid., p. 329.

91. F $12077 \mathrm{n}^{\circ} 88$.

92. Pierrard, P., La Vie quotidienne du prêtre français au $X I X^{\circ}$ siècle, 1801-1905, Hachette, 1986, p. 45 sig.

93. Ibid.

94. Ibid., p. 46. 
dados rasos de la Iglesia concordataria. Sin embargo, los sacerdotes españoles quienes lograron este tipo de colocación eran auténticos privilegiados en comparación con sus demás hermanos en religión que, por mucho que dijeran una misa cotidiana, sobrevivían en condiciones rayanas en la indigencia. Muy necesitados estaban pues, de los subsidios otorgados a los ex prisioneros de guerra por el gobierno de Carlos $\mathrm{X}$ a partir de diciembre de 1829 y, como ya hemos dicho, generosamente extendidos al conjunto de los refugiados por la monarquía de Julio, tras la revolución de 1830 . No obstante, tampoco faltó, entre los eclesiásticos españoles, algún que otro despabilado quien procuró aprovecharse de las ayudas sin estar verdaderamente en apuros. Por ejemplo, en agosto de 1833, el prefecto del Alto Garona rechazó la petición de subsidios presentada por dos ex religiosos españoles asilados en Bayona: el uno, Bernardo López, además de ser teniente de cura en una parroquia del departamento, tenía notorios ahorros que le permitían vivir holgadamente, mientras que el otro, Angel Vallejo, era propietario de una alquería y de una casa de pueblo en el departamento de Gers y también poseía sus ahorritos 95 . Por cierto, semejantes "ricos" eran casos aislados que no pueden ocultar el auténtico desamparo de la inmensa mayoría de sus compañeros.

Si económicamente hablando malvivieron, ¿cómo se portaron los clérigos liberales españoles refugiados? ¿qué opinión se merecieron? ¿qué sentimientos infundieron a los franceses?

A buen seguro, inspiraron compasión a los primeros franceses con los cuales estuvieron en contacto: los militares del ejército expedicionario. El propio duque de Angulema, hijo de Luis XVIII y jefe de estas tropas, instó repetidas veces al soberano español para que se mostrara clemente con los liberales, pero todo fue en vano.A estas alturas, después de derrotar a los constitucionales, los franceses se convirtieron en sus protectores y los convenios de capitulación, al deparar a los militares liberales la posibilidad de salir para Francia, aunque como prisioneros, fueron tablas de salvación para quienes pudieron acogerse a ellos ${ }^{96}$. Más tarde, los franceses siguieron ayudando a los que buscaban huir de las represalias. De este auxilio es un buen exponente el caso del ex religioso riojano Francisco Merino, quien temiendo la represión de los serviles, fue autorizado por el mismo Angulema a cruzar la frontera en diciembre de 1824, en un forgón que contenía documentos de contabilidad ${ }^{97}$. Similar suerte tuvo Manuel de la Torre, doctor en teología y cura párroco de San Justo y Pastor en Segovia, al que Amédée Guyot, ayudante de los hospitales militares, se llevó a Francia en dicembre de 1826 , como supuesto criado suyo ${ }^{98}$.

Ya llegados al país galo, sabemos con cuanta desconfianza era -lógicamente- custodiada su conducta política por los gobiernos de la Restauración. Pero aun así, en ocasiones, los sabuesos franceses podían manifestar cierta conmiseración: por mucho que la policía de Bayona considerara al ya referido fraile exclaustrado Gabriel Arrambide, agitador y espía, como un furibundo revolucionario de quien había que deshacerse, no vacilaba en subrayar que no se lo podía reexpedir a España sin ponerlo en peligro".

95. $\mathrm{F}^{7} 12105 \mathrm{n}^{\circ} 2050$.

96. Sánchez Mantero R., op. cit., p. 38.

97. $\mathrm{F}^{7} 12050 \mathrm{n}^{\circ} 1623$

98. $\mathrm{F}^{7} 12064 \mathrm{n}^{\circ} 2351$

99. F $11999 n^{\circ} 224$. 
Por otra parte, para la mayoría de los eclesiásticos emigrados, el obsesivo control ejercido por las autoridades carecía totalmente de objeto, por lo políticamente pasivos que permacieron. Era además su propio interés adoptar esta postura circunspecta y así lo recalcaba con meridiana claridad un informe del prefecto de Marsella en noviembre de 1824, afirmando que los asilados eran plenamente conscientes de que cualquier desliz político de su parte les expondría a sufrir medidas severas, entiéndase a ser expulsados ${ }^{100}$. Sometidos a tan estricta vigilancia, no podían ocultar ningún aspecto de su vida y los policías no se privaron de censurar la falta de rectitud moral de algunos clérigos. Pese a que la policía de la Restauración tuviera mucha propensión a hacer una amalgama entre "malas costumbres" y lo que para ella eran "malas opiniones y perversas doctrinas", hay que reconocer que contados sacerdotes no tuvieron una conducta ejemplar.

En octubre de 1824, un informe policial condenaba tajantemente los desenfrenos de Cristóbal Pueyo, ex religioso de la orden de San Bernardo, "conocida por ser la de los sibaritas del cenobitismo". Otrora capellán de la partida de guerrilleros capitaneada por Mina durante la guerra contra Napoleón, Pueyo ya se había refugiado en Francia en 1814 y había atendido una parroquia en el departamento de Charente. Destituido en 1821 por inmoralidad, volvió entonces a España. Emigrado de nuevo en marzo de 1824, sentó sus reales en Burdeos, donde vivía con una francesa de unos 23 años a la que hacía pasar por su hermana. De todo punto descarado e inmoral, ni se arredraba por comer en compañía de su manceba antes de celebrar misa en la parroquia de Saint-Pierre. Por si fuera poco, también frecuentaba las casas de prostitución y su probidad era más que sospechosa: habría embolsado indebidamente una cantidad destinada a rezar misas por el eterno descanso del alma de la condesa de Sástago. Y para remate, profesaba las más "odiosas" opiniones, hasta el punto de declarar, a la muerte de Luis XVIII, que muy pronto Francia estaría de nuevo de réquiem, por Carlos $\mathrm{X}$, y que así por fin se acabaría con los Borbones ${ }^{101}$.Tampoco brillaba por la honradez Raimundo María Salas, asilado desde 1823 y encargado de la parroquia de Frèche, en las Landas, hasta 1826. Privado entonces de su cargo por el obispo de Aire, tomó las de Villadiego llevando consigo algunos efectos mobiliarios que le había confiado el municipio y sin reintegrar sumas de consideración que había pedido prestadas a distintas personas ${ }^{102}$.Y ¿qué decir de la calamitosa historia del sacerdote Claudio Murquiz? Profesor de humanidades en Santiago de Compostela, desempeñó la cátedra de constitución durante el Trienio, por lo que tuvo que abandonar su patria en 1823. Primero nombrado teniente de cura en la Grande Terre (Guadalupe), consiguió, por motivos de salud, trasladarse a la metrópoli en 1826. Instalado en París pasó estrecheces, pero en 1832 gracias al apoyo de Alvaro Florez Estrada no sólo el gobierno de la monarquía de Julio le asignó un subsidio, sino que el diputado liberal, conde de Rémusat, se encargó de colocarlo como vicario. Poco duraron los días mejores, dado que en julio de 1833 , a los sesenta años, asesinó a puñaladas a su aposentadora, al parecer por conflictos financieros y por deseos de venganza, antes de pegarse un tiro en el corazón ${ }^{103}$.

100. $F^{7} 12023 n^{\circ} 658$.

101. $\mathrm{F}^{7} 12034 \mathrm{n}^{\circ} 1020$.

102. $F^{7} 11993$

103. $\mathrm{F}^{7} 12094 \mathrm{n}^{\circ} 1061$. 
Afortunadamente tan lamentables asuntos fueron excepciones y de ningún modo son de recibo las generalizaciones que tendían a hacer ciertos prefectos, alcaldes y policías de la Francia de la Restauración, quienes consideraban a priori a los clérigos españoles liberales como depravados y afirmaban rotundamente que los más de ellos tenían una conducta moral reprensible ${ }^{104}$. Al contrario, repitámoslo, la verdad más bien parece ser que la gran mayoría se portó con el decoro que correspondía a su hábito. Y, mal que les pesara a las autoridades, no faltaron algunos prefectos más ecuánimes quienes tributaron homenaje a su dignidad y rectitud.

Así en junio de 1824, un informe del prefecto del departamento de Gers encomiaba a Francisco Cisneros, oriundo de Monzón, en Aragón y refugiado en septiembre de 1823 por haber explicado la constitución a la juventud. Nombrado teniente de cura en Lézian por el prelado de Auch, su conducta ejemplar le había granjeado la estima de los feligreses y la benevolencia de los eclesiásticos de la comarca, únicas personas con las que alternaba.Todos, incluso los dignitarios de la diócesis, alababan a este pastor $^{105}$.Y en julio de 1827 , el prefecto de Lot y Garona destacaba que Antonio Barrón, sacerdote de origen riojano y ex capellán de un regimiento constitucional en Valencia, por muy adicto que fuese a la causa constitucional, siempre había guardado una actitud cuerda y decorosa en Agen, donde residía desde $1824^{106}$. Del mismo modo, según un informe de abril de 1827 , por su conducta "edificante", el presbítero aragonés de Barbastro, Joaquín María Falceto, gravemente comprometido en España por sus ideas liberales, emigrado en el departamento de Lot y encargado por el obispo de Cahors de la sucursal de Lamolairette, sólo merecía elogios y sus feligreses estaban muy satisfechos ${ }^{107}$.

A estas alturas, no resulta nada extraño que después de la revolución de 1830 , los prefectos de la monarquía orleanista se mostraran mucho más benévolos con los clérigos liberales asilados. Por cierto, en cuanto consiguió el reconocimiento oficial del Borbón madrileño, Luis Felipe dejó de apoyar los planes de invasión forjados por los liberales emigrados con vistas a restablecer el sistema constitucional en España. En cambio, no se hizo de rogar para conceder a los refugiados ayudas económicas, cuyo mínimo era de 45 francos mensuales ${ }^{108}$, lo que equivalía al sueldo de un obrero ${ }^{109}$. Poca cosa había de ser para quienes otrora disfrutaran de un beneficio o una prebenda, pero por lo menos, les permitía no morirse de hambre.Y, en numerosas ocasiones, los prefectos respaldaron calurosamente a los peticionarios de subsidios, resaltando cuan merecedores eran de la generosidad del gobierno, tanto por su conducta digna como por su fidelidad a la causa liberal. Incluso solian añadir consideraciones sicológicas, desacostumbradas en los informes administrativos, sobre cuan tristes y desamparados estaban.

Por contraste, excusado es decir que, por muy necesitada de pastores que estuviera la Iglesia francesa, la jerarquía religiosa siempre manifestó gran suspicacia y mucha cautela a la hora de otorgar a los eclesiásticos liberales españoles la licencia de rezar

104. $\mathrm{F}^{7} 12016 \mathrm{n}^{\circ} 570, \mathrm{~F}^{7} 12046 \mathrm{n}^{\circ} 1411$

105. $\mathrm{F}^{7} 12003 \mathrm{n}^{\circ} 395$.

106. $\mathrm{F}^{7} 11989$.

107. $\mathrm{F}^{7} 12056 \mathrm{n}^{\circ} 1939$.

108. Sánchez Mantero, R., op. cit., p. 137.

109. Lefranc, G., Histoire du travail et des travailleurs, Flammarion, Paris, 1975, p. 266. 
misa o de encargarles una parroquia. No lo disimulaba el arzobispo de Burdeos, quien negándose en mayo de 1824 a emplear en su diócesis a Pedro Elizondo, Francisco López de Velasco y Juan de Yriarte, ex capellanes del ejército constitucional, se preciaba de celar esmeradamente los sentimientos y opiniones que profesaba su clero y no quería exponerse a sentir remordimientos por valerse de sujetos tan sospecho$\operatorname{sos}^{110}$. Además, los clérigos que lograban la ansiada licencia o colocación, quedaban a la merced de que una denuncia de los feligreses o de sus hermanos en el sacerdocio les privara de la posibilidad de ganarse con qué subsistir.

Esta espada de Damocles cayó en 1831 en Joaquín Aguilar, a quien el obispo de Montauban expulsó de la parroquia de Delpech, en el departamento de Tarn y Garona, pues se sospechaba que participaba en las intrigas de los revolucionarios españoles ${ }^{111}$. En febrero de 1831, el ex profesor de teología en Barcelona y ex capellán Fontambas lamentaba no tener más remedio que colorear litografias para no morirse de hambre, dado que había sido privado del cargo de teniente de cura que desempeñaba en Aron, en el departamento de Mayenne, porque frecuentaba a los liberales del lugar. Después, se marchó a la corte con la esperanza de colocarse como capellán en un regimiento o en las colonias francesas, pero tanto el Limosnero mayor como el arzobispo de París rechazaban darle cualquier empleo ${ }^{112}$.Asimismo, por haber participado activamente en la revolución de 1830 -lo que le mereció ser condecorado con la medalla de Julio-, Sebastián Ortega fue destituido al año siguiente por el arzobispo de París de las funciones que desempeñaba en una parroquia de la capital francesa ${ }^{113}$. Otros muchos ejemplos similares podríamos exponer si no temiéramos cansar al lector y no cabe duda de que, estrechamente custodiados por la jerarquía religiosa -no en vano se moteaba entonces de "prefecto morado" al obispo-, los sacerdotes liberales españoles estaban sometidos a la mayor precariedad laboral y, por ende, económica.

Aunque las autoridades lo tuvieran por menos grave que las "malas costumbres" o las "malas opiniones", también se les reprochó pecar de ignorantes. Así lo formulaba, por antífrasis, el prefecto de Dordoña en septiembre de 1826, refiriendo que José del Moral, ex cura párroco de la iglesia de San Ildefonso de Granada, y a quien el obispo de Périgueux había encargado la parroquia de Ligneux, daba muestras de gozar de un nivel de instrucción muy superior al que solían tener los demás clérigos españoles. Siendo además digno y complaciente, se había granjeado la estima de sus feligreses ${ }^{114}$. En cambio, en marzo de 1833, si bien el prelado de Montauban reconocía las cualidades morales del dominico barcelonés exclaustrado Domingo Bergay -y a sabiendas de que éste había sido un "furibundo y muy activo revolucionario"-, desaconsejaba que el ministerio del Interior y de Cultos lo enviara de misionario en una colonia pues su ignorancia supina podría acarrear grandes desarreglos ${ }^{115}$. Es de suponer que, en el caso concreto de Bergay, su cortedad de luces tendría algo que ver con su antigua condición de fraile, como quiera que la ignorancia de los regulares precisamente deparó a los propios reformistas españoles uno de sus principales caballos de batalla a la hora de preconi-

110. $\mathrm{F}^{7} 11986$.

111. $F^{7} 12105 n^{\circ} 2197$.

112. $F^{7} 12092 n^{\circ} 946$.

113. $\mathrm{F}^{7} 12076$.

114. $F^{7} 12062 n^{\circ} 2250$.

115 . $F^{7} 12043 n^{\circ} 1281$ y F $19 n^{\circ} 5739$. 
zar la supresión, o cuando menos la drástica reducción de las órdenes religiosas. De todos modos, esa falta de preparación intelectual, varias veces puesta de realce por los franceses, contribuyó a empañar la imagen del clero español, aunque otra vez cabe matizar estas generalizaciones, y hemos visto que por lo menos un $20 \%$ de los eclesiásticos españoles exiliados gozaban de una buena instrucción.

A pesar de todo, por muy enterados que estuvieran los prelados galos de la indefectible adhesión de los sacerdotes españoles emigrados a las ideas liberales, no vacilaron en dar una mano compasiva a aquéllos cuya conducta les parecía sin tacha. En febrero de 1825, el obispo de Perpiñán salió en defensa del ex franciscano Juan Riera, -quien ya se había refugiado en Francia por primera vez después de la guerra de la Independencia-, acusado por la policía de conspirar y de ser un subversivo violento. Pero las autoridades civiles hicieron caso omiso de su opinón y Riera, expulsado, tuvo que salir del reino en octubre ${ }^{116}$. Por su parte, el arzobispo de Burdeos, cuyo recelo ya conocemos, no obstante saber que la conducta moral y política del ex capuchino Hermenegildo Llorens había descontentado tanto a sus feligreses de Olot que lo habían quemado simbólicamente, se dignó darle la licencia de decir misa pues nada tenía que reprocharle en su diócesis ${ }^{117}$.

Una conducta así de satisfactoria les valió a 12 de los clérigos liberales asilados obtener la autorización de fijar su domicilio en Francia y de disfrutar de los derechos civiles - lo que hoy llamaríamos el permiso de residencia. Semejante autorización sólo se otorgaba al cabo de un detenido y minucioso examen de la actitud del peticionario, y en el caso de los eclesiásticos, era de suma importancia la opinión de los prelados. En rigor, los sacerdotes españoles quienes presentaron esta solicitud no tenían la intención de renunciar a su nacionalidad pero el permiso de residencia, al sacarles de su condición de refugiados, ponía término a la quisquillosa vigilancia policial y les daba la facultad de desplazarse libremente en el reino. Mas, la principal motivación a la que obedecieron para solicitar dicho permiso era de tipo económico: había de conferirles una mayor seguridad de empleo y, a este respecto, resulta bastante significativo que 5 de los eclesiásticos autorizados a fijar su residencia fuesen tenientes de cura. Por otra parte, llama la atención que ninguno de los clérigos emigrados haya solicitado dicha autorización después de 1830 , o sea cuando podían cobrar los subsidios atribuidos a los refugiados.

Sin duda cabe matizar la opinión emitida por el doctor Marañón, al afirmar que en 1823 sólo permanecieron en Francia los liberales españoles templados, mientras los más exaltados pasaron a Inglaterra ${ }^{118}$. Por lo menos en lo que concierne al clero emigrado, la adopción de una conducta política cauta por muchos de los asilados no implica forzosamente que su adhesión al liberalismo fuera tibia.Al contrario, creemos haber demostrado que no faltaron sacerdotes refugiados cuyo compromiso con la causa constitucional era de todo punto sincero y ardoroso, a la par que meritorio por pertenecer a un colectivo que manifestó claramente su cerrazón.Y precisamente, el compromiso con el régimen de las Cortes les mereció a todos ser doblemente perseguidos, como liberales y como eclesiásticos. De ahí que no se atrevieran a aco-

116. Ibid. $\mathrm{y} \mathrm{F}^{29} \mathrm{n}^{\circ} 5695$.

117. $\mathrm{F}^{7} 12014 \mathrm{n}^{\circ} 464$.

118. Marañón, G., op. cit., p. 641. 
gerse al indulto concedido el 15 de Octubre de 1832 por Fernando VII porque, según temían, no les ponía a salvo de las persecuciones ejercidas por la jerarquía religiosa. De hecho, las autoridades galas reconocieron sin rodeos que estas amenazas no eran nada ficticias y aceptaron prorrogar las ayudas financieras que les habían asignado. Lo recalcaba expresamente el director general de la Policía en el ministerio del Interior en septiembre de 1833: dado el comprobado despotismo de la jerarquía eclesiástica española, el canónigo de Briviesca, Francisco de Borja Fernández desde luego se expondría a dar con sus huesos en un calabozo si volviera a su país ${ }^{119}$. Los clérigos liberales asilados en Francia tuvieron pues, que aguardar a que, tras la muerte del monarca, se acabara con el absolutismo y se iniciara una nueva era política en España. Sólo entonces el triunfo de sus ideas y la consecutiva amnistía otorgada por la reina regente María Cristina el 23 de octubre de 1833, les permitieron regresar, esta vez a mansalva, a su patria. 


\section{LISTA DE LOS ECLESIÁSTICOS LIBERALES EMIGRADOS A FRANCIA: 1823-1834}

\section{Abreviaturas:}

CO: Cárcel Orti Vicente: "Masones eclesiásticos españoles durante el Trienio liberal (1820-1823)" en Arcbivum bistoriae pontificae $n^{\circ}$ 9, Roma, 1971, p. 249-277

d: obtuvo la autorización de fijar su domicilio en Francia

DG: Dufour Gérard: Sermones revolucionarios del Trienio liberal (1820-1823), Instituto Juan Gil-Albert, Alicante, 1991, 211 p.

FB: Ferrer Benimeli José Antonio: Masonería, Iglesia e Ilustración, Tomo IV: La otra cara del conflicto, conclusiones y bibliografía, Fundación Universitaria Española, Madrid, 1977, p. 227-233

GI: guerra de la Independencia

GNA: Gil Novales Alberto: Diccionario biográfico del Trienio liberal, Ediciones El Museo Universal, Madrid, 1991, $737 \mathrm{p}$.

Guía: Sánchez de Haedo Julián y Escartín Mariano de: Guía del estado eclesiástico seglar y regular de España e Indias, Imprenta de Sancha, Madrid, 1819, 454 p. y 1820, 466 p.

n: natural de

p: subsidio prorrogado porque la amnistía del 15 de octubre de 1832 no ofrecía garantías contra la represión ejercida por la jerarquía eclesiástica española

pg: prisionero de guerra

r: $\quad$ regresó a España

s: obtuvo subsidios (generalmente 1,50 franco diario)

sf: $\quad$ sin fecha

TL: Trienio liberal

VA: Vauchelle Aline: Les Ouvrages en langue espagnole publiés en France entre 1814 et 1833, Université de Provence, 1985, 272 p.

1. AGUILAR Joaquín: sacerdote refugiado, destituido por el obispo de Montauban del cargo de teniente de cura que había conseguido en la parroquia de Delpech, en el departamento de Tarn y Garona, 1831 s Carcasona $\left(\mathrm{F}^{\top} 12105 \mathrm{n}^{\circ} 2197\right)$

2. AGUIRRE BENGOA Juan José de: canónigo racionero de Cuenca, nombrado durante el TL vicario general castrense de las provincias de Chinchilla, Cuenca y Guadalajara, comunero, condenado a cadena perpetua por motivos políticos 1831 s Bayona, 1832 París (Guía; F’12081 n² 263; FB)

3. ALBERO Braulio: n Hinojosa, Aragón, presbítero en Bano 1824 Agen: "malas opiniones", el obispo no le permitió decir misa, 1829 Périgueux ( $F^{7} 12046$ $\left.\mathrm{n}^{\circ} 1413\right)$

4. ALCOCER José María de: n 1764, párroco de Santa Cecilia de Medellín, Plasencia, uno de los más fervorosos predicadores del sistema constitucional en Extremadura, masón espontaneado, condenado a reclusión en un monasterio por la jurisdicción eclesiástica, logró escaparse 1829 Bayona, no autorizado a ejercer su ministerio, se trasladó a Burdeos y a Aix-en-Provence en 1830, s 1831, p 1833 Montpellier, $r 1834\left(\mathrm{~F}^{7} 12072 \mathrm{n}^{\circ} 2753\right.$ y $12078 \mathrm{n}^{\circ} 197$; CO)

5. ALVAREZY GUTIÉRREZ Pedro: n 1758 Sevilla, nombrado en el TL canónigo de la Colegiata de Baza (diócesis de Guadix), diputado a Cortes por Granada 1822-1823, autor de Respuesta a un impreso, que bajo el nombre de D. Ramón Feliú, ex-secretario de la Gobernación de 
la Península, ba circulado con El Universal, contra el informe que dio la Comisión de Cortes sobre la Memoria del ministerio de dicho ramo, Madrid, 1822

1824 Marsella, luego Aix, s 1831,p y r 1834 (Guía; F 12036 n $^{\circ} 1048,12023$ n $^{\circ} 658$ y 12078 n $^{\circ}$ 197; GNA)

6. AMATI Bernardino: sacerdote español, diputado a Cortes por Guadalajara de Nueva España, 1821-1822

1824 Burdeos: "malas doctrinas" (F¹1981 n 1 ; GNA)

7. APARICI José: n 1787 Moncada, capellán del $1^{\circ}$ batallón de Infantería del ejército constitucional

1823 pg Alençon, 1824 Inglaterra $\left(\mathrm{F}^{7} 12023 \mathrm{n}^{\circ}\right.$ 658)

8. ARRAMBIDE Gabriel: fraile exclaustrado, ya en Bayona en 1815, escribiendo folletos revolucionarios; en Pamplona en 1820

1822 detenido en Bayona como espía y conspirador al servicio del agente revolucionario Juan Olavarría, liberado y expulsado en enero de 1823

noviembre de 1823 en Bayona, tras escapar de la cárcel de Tolosa (España), donde estaba preso como criminal de Estado, " revolucionario ardoroso y peligroso", detenido, pero las autoridades francesas rechazaron extradirlo; suelto en julio de 1824 en virtud de una decisión del Tribunal de Primera Instancia de Bayona, se trasladó a Agen, no autorizado a rezar misa, vivía en la miseria, expulsado de Francia, en enero de 1826 procuró ir a Portugal y luego a Brasil, ambos países se negaron a recibirlo; marzo de 1826 obtuvo un pasaporte para Bélgica (F $11989,11999 \mathrm{n}^{\circ} 224$ y $12051 \mathrm{n}^{\circ} 1699$; GNA)

9. ASPERTEGUIA Agustín: capellán de un regimiento constitucional 1823 pg Bourges, 1824 Inglaterra $\left(F^{7} 11986\right)$

10. AZEMAR Ramón: eclesiástico

1823 pg Bourges, en febrero de 1824 se trasladó a París gracias al apoyo de la familia de Orléans, a la que había prestado algunos servicios durante la Revolución: S.A.R. habría vivido en casa del padre de Azemar, durante la emigración

En París solía ir a cenar a Palais Royal o a la casa que los de Orléans tenían en Neuilly, "buena conducta", 1828 se fue a Marsella ( $\left.\mathrm{F}^{7} 11986\right)$

11. BALSELLS Francisco: n 1791 Casate, Aragón, capellán del regimiento constitucional de Oviedo

$1823 \mathrm{pg}, 1824$ Agen (F'11989)

12. BARRAGÁN Antonio: n Arnedo, fraile agonizante, capellán del $1^{\circ}$ batallón de la Milicia Nacional de Zaragoza y miembro de la Tertulia Patriótica de la misma, masón

enero de 1825 Bayona, no autorizado a decir misa, indigente, "exaltado, de pésimos principios políticos", expulsado, se marchó para lnglaterra en marzo

Allí se hizo pastor protestante, se casó, pero su mujer murió de parto, sobrevivió como chocolatero

Autor de Discurso leído en la tertulia patriótica de Zaragoza en la tarde del 7 del corriente, con motivo...del artículo 12 de la constitución (F¹2050 n ${ }^{\circ} 1663$; GNA; FB)

13. BARRÓN Antonio: 1781 Nalda, La Rioja, capellán del regimiento constitucional de Logroño 1823 pg, 1824 Agen donde ejerció su ministerio, d 1826 "muy adicto al sistema constitucional, pero siempre se ha portado con circunspección y cordura desde que está en Francia” (F'11989)

¿será el mismo que Agustín Barrón, lector de teología del convento de franciscanos de Logroño, miembro de la Sociedad patriótica de la misma y autor de Oración sacro patriótica que pronunció el día 9 de junio de 1820 en la insigne Catedral de la ciudad de Logroño el R.P.Fr. Agustín Barrón, maestro de teología en el Convento de S. Francisco y catedrático interino en el Seminario Conciliar de la misma en la solemne acción de gracias que la Sociedad de Amigos amantes de la Constitución, celebró con motivo de la instalación del soberano congreso nacional? (DG; GNA) 
14. BERGAY Domingo: n 1785 Barcelona, dominico exclaustrado luego teniente de cura en San Miguel, Barcelona

1825 Montauban, "se porta bien pero opiniones muy favorables al partido constitucional" 1829 solicitó un pasaporte para España, pero las autoridades francesas lo disuadieron: "fue uno de los revolucionarios más activos, por lo tanto se expondría a sufrir represalias y persecuciones"

1831 s Montauban pues su único recurso consistía en rezar una misa diaria por la que cobraba 1 franco,p 1833

1833 el obispo de Montauban no tenía nada que reprocharle pero desaconsejaba al ministerio del Interior y de Cultos que lo mandara de misionario en una colonia porque su ignorancia supina podía ocasionar serios problemas $\left(\mathrm{F}^{7} 12043 \mathrm{n}^{\circ} 1281\right.$ y $12088 \mathrm{n}^{\circ} 685$, F19 $\mathrm{n}^{\circ}$ 5739)

15. BOADELLA Juan: n Gerona, dominico secularizado, capellán del ejército constitucional 1823 pg, 1831 daba clases en el Real Colegio de Clermont-Ferrand 1832 s Tours, p 1833 París, $r 1834$ (F $\left.12090 n^{\circ} 801\right)$

16. BONDÍA Domingo: n 1778 Maella, Aragón, ex religioso en Alcaniz, capellán en el ejército de Ballesteros, masón espontaneado

1824, amedrentado por las amenazas cuyo blanco era en Zaragoza, llegó a Tarbes y a continuación se asentó en Bagnères de Bigorre: "excelente moralidad y buena conducta" 1825 Auch, provocó gran escándalo, intentando suicidarse en 1829, de ahí su traslado a Burdeos $1832 \mathrm{~s}$ Burdeos por estar sin recursos: no podía ejercer su ministerio pues no hablaba el francés $\left(\mathrm{F}^{7} 12028 \mathrm{n}^{\circ} 840\right.$ y $\left.12094 \mathrm{n}^{\circ} 1042 ; \mathrm{CO}\right)$

17. BORJA FERNÁNDEZ Francisco de: n 1763, canónigo magistral de Briviesca, diócesis de Burgos, recluido en un monasterio en 1823

1831 Bayona, 1832 París donde solicitó subsidios, aportando un atestado de Espoz y Mina que confirmaba que Borja era preso de Estado en España y había sido de todo punto despojado de los considerables bienes que poseía, $\mathrm{p} 1833$ (Guía; $\mathrm{F}^{\top} 12081 \mathrm{n}^{\circ} 262$ )

18. BORONAT Francisco: capellán

1823 pg en el depósito de Briançon

1824 se embarcó en Marsella, rumbo a Barcelona ( $\left.\mathrm{F}^{7} 11985\right)$

19. BOVER José: desterrado por motivos políticos, sospechoso de conspirar encarcelado en Perpiñán durante 6 meses bajo Carlos $\mathrm{X}$

1831 s Aix-en-Provence pues sólo tenía el producto de alguna misa ocasional para mantenerse $\left(\mathrm{F}^{7} 12080 \mathrm{n}^{\circ} 231\right)$

20. CALDERÓN Juan: ex religioso

1824 Bayona, profesor de idiomas

1829 se marchó para Inglaterra $\left(\mathrm{F}^{7} 12070 \mathrm{n}^{\circ} 2674\right)$

21. CARRASCO Y OSORIO Juan: ex capellán militar durante la GI condecorado en Bailen, Zaragoza y Rioseco, nombrado en el TL canónigo honorario de Manila, Filipinas, y beneficiado de Majadahonda, Madrid,

1823 Montpellier, "muy adicto al régimen de las Cortes"

1825 teniente de cura en Salinelle, cerca de Nimes, estimado por los feligreses $1831 \mathrm{~s}$ en Aviñón, p 1833, r 1834 (Guía; F'12046 n 1411)

22. CEBRIÁN Antonio: $n$ Córdoba, luchó en el bando patriótico durante la GI, lo que le mereció el título de "bemérito de la patria", capellán del $2^{\circ}$ regimiento de Artillería de Valencia durante el TL, comunero

1826 cuando se retiró de Barcelona el ejército francés, de cuya protección gozaba, pasó a Perpiñán donde estuvo agregado al clero de la parroquia de la Real

1829 s París, 1833 ejercía de nuevo su ministerio en Perpiñán (F¹2071 n²684 y 12103 $\left.\mathrm{n}^{\circ} 1788 ; \mathrm{FB}\right)$

23. CISNEROS Francisco: n 1775 Monzón, Aragón, predicó la constitución a la juventud 1824 Auch, encargado de la parroquia de Lézian,"conducta edificante"

1831 s en Burdeos, p 1833 (F $12003 n^{\circ} 395$ y $12089 n^{\circ} 714$ ) 
24. COMMASSOUS José María: n 1791 Gerona, ex mercedario,

1827 Perpiñán, comprometido por sus opiniones y su conducta durante la revolución de España marzo de 1828 Lila, mayo r a España $\left(\mathrm{F}^{7} 12065 \mathrm{n}^{\circ} 2459\right)$

25. CORTADELLAS Pedro José: n 1786 Cervera,

1825 Marsella, refugiado a causa de sus antecedentes políticos, luego Perpiñán y Aurillac, Cantal, donde estuvo autorizado a decir misa 1830 París $\left(\mathrm{F}^{7} 12057 \mathrm{n}^{\circ} 1993\right)$

26. CORTES Juan: n 1781 Afrancesado ya en Francia en 1814; luego capellán de un regimiento constitucional, durante el TL

1823 pg, 1829 París, sacerdote adscrito a la parroquia de los Petits Pères, s 1831 (F¹2086 $\left.\mathrm{n}^{\circ} 552\right)$

27. COSTA Juan: n 1788, religioso exclaustrado, vicario en Vich, predicó a favor de la constitución

1823 Perpiñán: "muy adicto al partido revolucionario, siente un profundo odio hacia el gobierno realista"

1824: residencia vigilada en Laval, Mayenne $\left(\mathrm{F}^{7} 12015 \mathrm{n}^{\circ}\right.$ 511)

28. COUMASSOUS Alejandro: fraile secularizado, cabo en el $1^{\circ}$ batallón de cazadores de Barcelona

1824 preso en el fuerte de Briançon ( $\left.\mathrm{F}^{\dagger} 11985\right)$

29. CRESPO Vicente: 1827 llegó a Marsella, tras 3 años de reclusión en España, se trasladó a Aix a iniciativa de Antonio Posada y Rubín de Celis, ejerció su ministerio en la parroquia de la Madeleine

1831 s Aix, 1832 Montpellier $\left(F^{7} 12069 n^{\circ} 2625\right.$ y $\left.12079 n^{\circ} 199\right)$

30. CRISTÓBAL Francisco: n Valencia, doctor en teología, vicario en la Colegiata de San Felipe de Játiva

1823 se escondió en distintas ciudades españolas hasta 1830 , fecha en que fue hecho preso, sentenciado por una Junta de fe, "tribunal más terrible que la extinta Inquisición", cumplió 10 meses de reclusión

1831 Marsella: miseria, s, p 1833 (Guía; $\mathrm{F}^{7} 12089$ n 745)

31. CRISTÓBAL Narciso: n 1789 Calahorra, capellán del regimiento constitucional de Logroño $1823 \mathrm{pg}, 1824$ Agen, autorizado a decir misa, buena conducta

febrero de 1826 d, pero en un informe con fecha del 13 de marzo, el prefecto de Lot y Garona se quejaba al ministerio del Interior de que semejante decisión se hubiera tomado sin consulta previa con la policía y lamentaba que el ministro de Justicia diera con tanta precipitación un título legal para permanecer en el reino a sujetos muy peligrosos ( $\mathrm{F}^{7} 11989$, $\left.\mathrm{F}^{19} 5659\right)$

32. CUESTA Y TORRE Antonio de la: n 1755 Liérganes, Santander, racionero de la Catedral de Avila, arcediano y penitenciario de los hospitales de la misma, 1790 protegido por Godoy, director del hospicio de San Joaquín en Avila, 1800 sentenciado por el Santo Oficio de Valladolid a una pena de reclusión por jansenista y sospechoso de simpatía hacia la Revolución francesa, se escapó a Bayona donde le dio cobijo el conde de Cabarrús 1808 rechazó ser consejero de Estado del "rey intruso" y se trasladó a Cádiz, 1814 detenido por los absolutistas

1820-1822 diputado a Cortes por Avila

febrero de 1824 Burdeos,donde frecuenta a otros refugiados, "hombre dotados de grandes talentos, pero de opiniones exaltadas"

noviembre de 1824 París, considerado por la policía como un verdadero estadista, de amplios conocimientos, y esta vez juzgado como un moderado

1828 solicitó un visado para Londres, pero la muerte le alcanzó en Calais, el 18 de julio (Guía; $\mathrm{F}^{7} 11984 \mathrm{n}^{\circ} 2$; GNA) 
33. DOMÍNGUEZ NAVARRO Francisco: n Cambres de San Bartolomé, nombrado durante el TL cura párroco de San Juan del Puerto, Sevilla

1824 Bruselas, refugiado por motivos políticos

1831 Calais, 1832 Rouen donde solicitó subsidios, presentando un atestado del general Quiroga, también refugiado en Normandía (Elbeuf), se le asignó la cantidad acostumbrada de 1,50 franco al día, $\mathrm{r}$ diciembre de 1832 (Guía; $\mathrm{F}^{7} 12101 \mathrm{n}^{\circ}$ 1588)

34. ELIZONDO Pedro: capellán de un regimiento constitucional

$1823 \mathrm{pg}, 1824$ pidió permiso para instalarse en Burdeos donde pensaba poder ganar con qué vivir ejerciendo su ministerio, pero el arzobispo de Burdeos se lo denegó (F711986)

35. ESCARIGAS Manuel: n 1778 Ripoll, presbítero, predicador de la constitución 1823 Perpiñán, 1824 Laval, 1826 Burdeos, d 1827 (F¹2026 n 768)

36. ESCARIO José: eclesiástico, miembro de la Diputación Provincial de Galicia y de la Real Academia de Historia

1823 Inglaterra, febrero de 1832 La Rochelle s 75 francos mensuales, septiembre Burdeos (F'12093 $\mathrm{n}^{\circ}$ 984)

37. ESPINAL Juan: presbítero 1825 refugiado por motivos políticos, ejerció su ministerio en París 1831 privado de recursos "a causa de la competencia del clero francés y quizá por haber cantado Dominen salvum fac regem nostrum Filipum, $\mathrm{s}\left(\mathrm{F}^{\urcorner} 12077 \mathrm{n}^{\circ} 88\right)$

38. EYRALDE Julián: n 1774, capellán de un regimiento constitucional

$1823 \mathrm{pg}, 1824$ teniente de cura en una parroquia de Dordoña

1832 Burdeos, casi ciego, $s\left(F^{7} 12096 n^{\circ} 1219\right.$ y $\left.12099 n^{\circ} 1418\right)$

39. FALCETO Joaquín: n 1778 Barbastro, Aragón, presbítero

1825 gravemente comprometido por su conducta política y su adhesión al sistema constitucional, abandonó su patria por temor a ser perseguido, no autorizado a ejercer su ministerio en Auch, Gers

1826 Montauban, Tarn y Garona,

1827 d Castelnau de Montralier, Lot, donde ejercía su ministerio así como en Lamolairette, en que los feligreses estaban muy satisfechos $\left(F^{7} 12056 n^{\circ} 1939\right)$

40. FEIJOO Lorenzo: eclesiástico, director de un centro de instrucción pública

1824 Courbiac, Lot y Garona, discursos subversivos, mantenía una muy activa correspondencia con España y se sospechaba que pertenecía a sociedades secretas, pero no lo hemos encontrado en las listas de eclesiásticos masones españoles levantadas por Vicente Cárcel Orti y José Antonio Ferrer Benimeli ( $\mathrm{F}^{7} 11989$; GNA)

41. FERRER Juan: n 1779 Mallorca, doctor en teología, promovido en el TL beneficiado de la Catedral de Mallorca y protonotario

1828 Aviñón, abandonó su patria, perseguido por motivos políticos, s 1831

1833 París, una misa diaria en la iglesia Saint-Méry, $\mathrm{p}$

1835 asesinado en París por Benito Pereira, ex religioso español, oficial de ebanista y ya autor de distintos hurtos en Francia; sin duda Pereira mató a Ferrer para robarle como quiera que, al ser detenido, llevaba consigo el reloj de éste (Guía; $\mathrm{F}^{7} 12089 \mathrm{n}^{\circ} 708$ )

42. FLAQUER Mauricio: $n$ 1788, ex mercedario

1823 Perpiñán, "adicto al partido revolucionario, siente un profundo odio hacia el gobierno realista", solicitó residir en Prades o en Céret, cerca de Perpiñán

1824 residencia vigilada en Laval, Mayenne $\left(F^{7} 12015 n^{\circ} 511\right)$

43. FOCEÁN Francisco: capellán de un regimiento constitucional

1823 pg, 1833 s París (F $12013 \mathrm{n}^{\circ}$ 1783)

44. FONT Joaquín: n 1790 Barcelona, capuchino exclaustrado,

1823 Perpiñán:" furibundo revolucionario", enviado a Laval, residencia vigilada 1824 ejercía su ministerio en la parroquia de Saint-Louis de Burdeos, el obispo no tenía nada que reprocharle 1827 Le Mans, solicitó la autorización de fijar su domicilio en Francia, pero considerado como "un sujeto de muy malas costumbres", no la consiguió $\left(\mathrm{F}^{7} 12014 \mathrm{n}^{\circ} 464\right)$ 
45. FONTAMBAS: n 1790, profesor de teología en Barcelona

1823 refugiado en Francia, teniente de cura en Aron, Mayenne y luego destituido porque alternaba con los liberales franceses de la comarca

se marchó a París con la esperanza de conseguir una capellanía en un regimiento o en las colonias francesas, pero tanto el Limosnero Mayor como el arzobispo de París rechazaron darle un empleo, tuvo que colorear litografias y colocarse de dependiente para sobrevivir 1831 s Patís (F¹2092 n 946)

46. FUENTES José Francisco: sacerdote español refugiado

1829 Tolosa desde algunos años, solicitó ir a París por asuntos personales

Ya en la capital, frecuentaba a Martínez de la Rosa, al librero francés Hector Bossange y con la ayuda financiera del otrora afrancesado Alejandro Aguado, banquero en París, formó el proyecto de poner un comercio de productos españoles: vinos, frutas... (F $12072 \mathrm{n}^{\circ} 2742$ )

¿será el mismo que el masón Francisco Fuentes, cura párroco de Ciudad Rodrigo? (CO)

47. GALLEGO Juan Nicasio: n 1777 Zamora, 1800 director eclesiástico de los caballeros pajes de SMC, 1809 racionero de Cartagena, 1810 diputado a las Cortes de Cádiz por Murcia, 1814 recluido en un monasterio

1820 liberado y nombrado arcediano mayor de Valencia, otra vez destituido y perseguido en 1824, se refugió a Barcelona, al amparo del ejército francés

1827 cuando las tropas de Angulema se retiraron de la Ciudad Condal, emigró a Montpellier, donde publicó en 1828, en la imprenta de Martel joven Elegía a la muerte de Nuestra Señora, Doña María Isabel de Braganza, imprenta de Martel jóven, 10 p. Le valió quizá este poema la posibilidad de regresar a España, 1830 académico de la Lengua, 1833 juez del Excusado, supernumerario de la Rota de la Nunciatura, 1834 censor de periódicos, 1839 académico secretario de la Española, 1845 Senador del Reino, y 1852 arcipreste del Pilar de Zaragoza (Guía; GNA;VA p. 203)

48. GAONA Bernardo: capellán de un regimiento constitucional $1823 \mathrm{pg}$

1833 teniente de cura en la parroquia de Tapian, cerca de Burdeos, muy estimado por los fieles $\left(\mathrm{F}^{7} 12105 \mathrm{n}^{\circ} 2042\right)$

49. GÁÑEZ Jerónimo: 1828 refugiado en Montauban desde varios años por adhesión al sistema constitucional, provocó escándalo por sus malas costumbres

enero de 1829 Limoges, donde llegó acompañado por su sedicente sobrina, causante del escándalo, febrero se embarcó en Calais con rumbo a Inglaterra ( $F^{7} 12069 n^{\circ} 2623$ )

50. GARCÍA Manuel: n 1790 Cartagena, capellán de lanceros $1823 \mathrm{pg}$ en Alençon, Orne

1824 Inglaterra, se le incautó en Calais una carta del coronel Ignacio Cavero dirigida a Miguel del Riego, hermano de Rafael y canónigo de Oviedo, emigrado en Londres $\left(\mathrm{F}^{7} 12021 \mathrm{n}^{\circ}\right.$ 619)

51. GARCÍA Ramón: n 1790 Peralta, Navarra, capuchino exclaustrado

1823 emigró a Francia

1825 autorizado a decir misa en Estillac, cerca de Agen, se elogiaba su conducta $\left(F^{\top} 12050\right.$ $\mathrm{n}^{\circ} 1657$ )

52. GARROS Tomás: sacerdote

1823 Perpiñán, solicitó permiso para instalarse en Marsella $\left(F^{\urcorner} 12014 n^{\circ} 465\right)$

53. GATUELLAS Antonio: 1823: emigró a Montpellier por motivos políticos

1827: encargado de la parroquia de Prades, el obispo de Montpellier estaba satisfecho de su conducta

1830: s Limoges, pero el clima era perjudicial para su salud, pidió permiso para instalarse en Agen

1831: teniente de cura en Envals, gracias al apoyo del obispo de Agen, se le suprimió el subsidio pues ya no lo necesitaba $\left(\mathrm{F}^{7} 12081 \mathrm{n}^{\circ} 329\right.$ y $\left.\mathrm{F}^{19} 5688\right)$ 


\section{GÓMEZ José: n Calahorra}

1824 Bayona, tras sufrir varios meses de reclusión en España por su adhesión al régimen de las Cortes 1825 Agen, autorizado a decir misa, 1828 Pau $\left(F^{7} 12050 n^{\circ} 1615\right)$

55. GONZÁLEZ VALLEJO Pedro: 1770 Soto de Cameros, Logroño, doctor en derecho canónico por la Universidad de Zaragoza, provisor y vicario general de la diócesis de Segovia, 1819 obispo de Mallorca

1820-1822 diputado a Cortes por Soria, Presidente de las mismas en 1820, miembro de la Diputación permanente de Cortes en 1822, autor de Pastoral dirigida a todos los fieles de su diócesis en 11 de noviembre de 1822 y de Discurso dirigido a la milicia nacional voluntaria de Palma en el acto de la bendición de la bandera, 1822 noviembre de 1824 emigró a Montpellier con un sobrino, una sobrina y su secretario junio de 1825 obligado a dimitir de su mitra a petición del nuncio Giustiniani 1825 siempre en Montpellier, vivía tranquilo y conducta irreprochable

1830 se trasladó con su familia a Bagnères de Bigorre, por motivos de salud y con la intención de regresar pronto a España (GNA; $\mathrm{F}^{7} 12045 \mathrm{n}^{\circ} 1386$ )

56. GUILLÉN DE MAZÓN Antonio: Prebendado profeso de la orden de Montesa y prior del hospital general de Barcelona

1814 probablemente afrancesado, refugiado en Perpiñán, donde frecuentaba asiduamente a José Marchena y, como éste, se entregaba a la agitación revolucionaria desde el exilio

1820 Barcelona, donde al parecer dirigió el Diario constitucional de Barcelona...1820 y El Indicador catalán, 1822-1823, se dijo que era masón, pero no es hecho comprobado, 1822 miembro de la Tertulia Patriótica de Barcelona

1823 emigró a Francia, donde colaboró con la policía redactando numerosos informes sobre destacados políticos españoles 1833 dio a luz en Burdeos una Memoria dedicada al Rey N. S. sobre la conveniencia de una institución académica para la propagación de la Religión cristiana

junio de 1834 teniente de cura en Camarsac, cerca de Burdeos, solicitaba una ayuda económica para regresar cuanto antes a España, porque, según afirmaba, sus amigos esperaban oirle predicar en la Catedral en la gran celebración del 24 de julio, como solía hacer antes, en calidad de Primer Orador del Municipio Constitucional.Ahora bien, al cabo de 2 meses de enfermedad, resultaban agotados sus recursos; julio de 1834 considerándole un hombre sabio, moral y razonable, de todo punto digno de la confianza y de la benevolencia del gobierno por su conducta y sus opiniones políticas, las autoridades de la monarquía orleanista le concedieron un viático de 0,50 franco por legua hasta Perpiñán

junio de 1835 se publicó en Perpiñán, en la imprenta de Jean Alzine Palabras de un católico o Defensa del orden social, que Guillén de Mazón había traducido libremente del libro escrito por Octavien Adolphe Vidal, como impugnación de Paroles d'un croyant, obra dada a luz por Lamennais en 1834 (GNA; $F^{\top} 12016 n^{\circ} 2176 ;$ Bibliograpbie de la France, imprenta de Pillet aîné, Paris, 1835)

57. HERNÁNDEZ José Ramón: n 1780 Albacete, presbítero 1824 refugiado en Francia por motivos políticos, $1832 \mathrm{~s}$ Burdeos, p $1833\left(\mathrm{~F}^{7} 12092 \mathrm{n}^{\circ}\right.$ 947)

58. HOYOS NORIEGA José: eclesiástico

1827 desembarcó en Cherbourg, Normandía, procedente de Berja, Granada y solicitó el permiso de ir a Aix-en-Provence, para vivir junto a su tío Don Antonio Posada y Rubín de Celis (F $12065 \mathrm{n}^{\circ}$ 2431)

59. HOZ Miguel de la: 1796 Hernani, religioso de la orden de San Basilio

1830 Bayona, huyendo de las persecuciones de las que era víctima debido a sus opiniones políticas

1831 s Burdeos pues sólo tenía el producto de alguna misa ocasional para mantenerse, mísero, según confirmaba el prefecto

1832 se le concedió una ayuda excepcional, equivalente al subsidio de un mes y medio para que pudiera ir a buscar fortuna a América, lo que hizo embarcando en mayo con rumbo a Buenos Aires $\left(\mathrm{F}^{7} 12078 \mathrm{n}^{\circ} 129\right)$ 
60. ITURBIDE Juan Manuel: capellán de un regimiento de Infantería

1830 Bayona, 1831 s Périgueux pues el obispo de dicha ciudad no quiso, a causa de las ideas liberales de Iturbide, ratificar el permiso de ejercer su ministerio que éste ya había conseguido en Bayona y luego en Aire, Landas $\left(\mathrm{F}^{\top} 12079 \mathrm{n}^{\circ} 183\right)$

61. LARRUMBE Y CUBO Antonio Buenaventura: n 1790 Aro, doctor en teología, física y matemáticas, canónigo honorario y catedrático de derecho constitucional en la Universidad de Estella, diócesis de Pamplona

1823 Bayona, 1824 Burdeos donde decía misa en Saint-Sevrin y se había granjeado la confianza del párroco; pero malas costumbres: acusado de frecuentar a las mujeres públicas; también políticamente sospechoso: delatado por un compatriota suyo ("el Moderado") por tener opiniones exaltadas y por querer matar a Fernando VII. Después de investigar más detenidamente, la policía consideró infundadas esas calumnias tanto en lo político como en lo moral, pero se lo quiso expulsar del reino

noviembre de 1824 formó el proyecto de embarcarse hacia Florida, no obstante se lo impidieron problemas de salud, obtuvo un plazo y acabó colocándose como ayo en casa del coronel de Infantería, Señor de Soyres, de muy buena fama; febrero de 1826 Angulema y regresó a Burdeos en mayo

1831 s Burdeos, p en $1833\left(F^{7} 12016 \mathrm{n}^{\circ} 570\right.$ y $\left.12092 \mathrm{n}^{\circ} 960\right)$

62. LÓPEZ Bernardo: ex religioso, sf asilado en Francia para escapar del "despotismo monacal" 1833 Tolosa, solicitó una ayuda económica, pues el arzobispo acababa," por un acto de absolutismo escandaloso" -según afirmaba- de destituirle de la parroquia en la que era teniente de cura; subsidio que le fue denegado pues tenía ahorros ( $\left.\mathrm{F}^{7} 12105 \mathrm{n}^{\circ} 2050\right)$

63. LÓPEZ Salvador: n 1781 Málaga, canónigo de Berlanga en la diócesis de Sigüenza, enseñó derecho natural y constitucional en la Universidad de Sevilla durante el TL, masón 1823 emigró por motivos políticos

1831 s Montpellier: sólo se mantenía gracias a alguna que otra misa y a la caridad de algunos conocidos, 1833 p por ser "un enconado constitucional", r 1834 (F”12084 n 420; FB)

64. LÓPEZ CAYUELA Juan: n 1771 Murcia, capellán de guardiamarinas 1823 pg Alençon, luego ejerció su ministerio en La Capelette, cerca de Marsella; indigente, $\mathrm{s} 1832$, p $1833\left(\mathrm{~F}^{7} 12079 \mathrm{n}^{\circ} 194\right)$

65. LÓPEZ de VELASCO Francisco: n Burgos, capellán de un regimiento constitucional 1823 pg, 1824 Auch: "buena conducta", 1826 ejercía el sacerdocio en Montauban, d 1828 (F`11986)

66. LLEVARÍA José: n 1792, presbítero, predicó la constitución 1823 desembarcó en Port-Vendres, cerca de Perpiñán, deseando ir a Marsella (F¹2015 $\mathrm{n}^{\circ} 511$ )

67. LLOPIS Antonio: n Mahón, Menorca, capellán del $9^{\circ}$ regimiento de Infantería de línea 1829 refugiado en Marsella para huir de las persecuciones del gobierno: se sospechaba que estaba en inteligencia con Torrijos

1830 s Burdeos: sólo algunas misas en la parroquia Sainte-Croix, situación muy infeliz, rayana en la inopia, según el prefecto de Gironda $\left(F^{7} 12100 n^{\circ} 1522\right)$

68. LLORENS Hermenegildo: capuchino exclaustrado, párroco de Olot y luego de Hospitalet 1823 Perpiñán "dejó tan malos recuerdos en Olot que fue quemado simbólicamente, todavía urde proyectos revolucionarios"

1824 Burdeos y luego Agen: no autorizado a ejercer el sacerdocio; 1825 regresó a Burdeos, donde el arzobispo le concedió licencia de decir misa, a pesar de sus opiniones políticas, porque no tenía nada que reprocharle desde que vivía en su diócesis $\left(F^{7} 12014 \mathrm{n}^{\circ} 464\right.$ y $\mathrm{F}^{19} 5672$ )

69. MAESTRE José: presbítero

1832 refugiado, teniente de cura en Les Barils, Évreux, Normandía, 1833 r España (F712103 $\mathrm{n}^{\circ} 1826$ ) 
70. MARCO Manuel: n Vall de Uxó, Valencia, párroco de Puig, capellán de un batallón constitucional, 1823 recluido en España: 4 años

1828 emigró a Francia

1831 s Aix, p 1833, r $1834\left(F^{7} 12074 n^{\circ} 2812,12104 n^{\circ} 1841\right.$ y $\left.12080 n^{\circ} 204\right)$

71. MARCÓBAL Juan Pablo: n 1785 Barcelona, agustino exclaustrado, capellán de un regimiento constitucional, "liberal exaltado", hecho preso por El Trapense

1823 emigró a Francia, 1824 Pompignan, autorizado por el obispo de Nîmes a ejercer el sacerdocio, conducta irreprochable, d $1826\left(\mathrm{~F}^{7} 11986\right)$

72. MARIANO Agustín: n Fraga, presbítero

1823 refugiado en Francia, "ejerció el sacerdocio en distintas parroquias en los alrededores de Tolosa donde gozaba de estima, luego "obligado a colgar el hábito bajo presión de la jerarquía eclesiástica, debido a sus opiniones marcadamente liberales" 1832 s Tolosa, $\mathrm{r}$ marzo de $1833\left(\mathrm{~F}^{7} 12094 \mathrm{n}^{\circ} 1090\right)$

73. MARTÍ José: n 1791 Barcelona, presbítero

1828 Perpiñán huyendo de las persecuciones a las que estaba sometido como partidario del sistema constitucional, luego Aviñón

1831 s Aix: sólo cobraba el producto de una misa diaria en la parroquia de la Madeleine, $r$ junio de 1833 (F $12069 \mathrm{n}^{\circ} 2599$ y $12080 \mathrm{n}^{\circ} 203$ )

74. MATA de ECHEVERRÍA Juan: ex mercedario y lector de teología en el convento de la Merced Calzada de Pamplona, 1820 miembro de la Sociedad Patriótica de Pamplona, autor de Oración eucarística, que en la solemne función, que en el convento de PP. Franciscanos de la ciudad de Pamplona celebró la Sociedad Patriótica de la misma con el abjeto de dar las gracias al todopoderoso por ver llegado el deseado día 9 de julio e implorando el favor del cielo para los representantes de la Nación reunidos en Cortes, 1820 y de Oración fúnebre que en las exequias celebradas en esta corte por el coronel Cruchaga dijo...1822, masón, espía al servicio del agente revolucionario Juan Olavarría 1824 Burdeos, luego París donde intentó "vender" a la policía informaciones sobre supuestas tramas urdidas por los constitucionales, afirmando ser en realidad un agente secreto de Fernando VII, infiltrado entre los conspiradores liberales; parece que, en efecto había mantenido relaciones con la "camarilla" real, o cuando menos, con el influyente secretario particular del monarca,Antonio Ugarte. Con todo, en 1824 era persona non grata en España

septiembre de 1824 Tournai, Bélgica, luego Lila, expulsado, Londres

1827 Madrid, 1828 Perpiñán, luego Moulins, Allier, 1829 París y terminó embarcando en Le Hâvre, en abril de 1830, para buscarse la vida en Puerto Príncipe (GNA; DG p. 110; nuestro artículo en Trienio, Ilustración y liberalismo $n^{\circ} 27$, mayo de 1996, Madrid, p. 73-82)

75. MATARÓ José: n 1763 Vich, religioso secularizado, profesor de teología en Vich, comprometido por haber predicado la constitución

1823 Port-Vendres, 1824 Laval solicitó trasladarse a Saint-Jean d'Angély, Charente, donde el cura deseaba encargarle una parroquia filial pero le fue denegado: "sus opiniones políticas y sus antecedentes no permiten confiar en él"; pidió entonces ir a Ernée, cerca de Laval, donde el conde Desnon, uno de los más ricos propietarios de la comarca, ofrecía darle cobijo; siendo un fiel servidor del Rey, Desnon vigilaría a Mataró; 1825 éste solicitó trasladarse a París para ser capellán en un convento de monjas carmelitas; rechazado: conducta satisfactoria en Ernée: que se quedara allí $\left(\mathrm{F}^{7} 12026 \mathrm{n}^{\circ} 768\right)$

76. MEDRANO Ildefonso: n 1783, presbítero, capellán de un regimiento constitucional, masón 1823 Marsella, 1824 Inglaterra, 1826 breve estancia en París: sin novedad, y volvió a Londres (F7 $12014 \mathrm{n}^{\circ} 486$; FB)

77. MEDRANO Manuel Tomás de: n 1779 Cádiz, presbítero

1825 La Rochelle, comprometido en España por motivos políticos, nombrado teniente de cura en la parroquia de Matha, cerca de Saint-Jean d'Angély, Charente ( $\left.\mathrm{F}^{7} 12057 \mathbf{n}^{\circ} 1975\right)$

78. MERINO Francisco Martín: 1788 Arnedo, La Rioja, ex franciscano en Santo Domingo de la Calzada, liberal exaltado 
diciembre de 1824 Bayona, temiendo el restablecimiento de la Inquisición, gracias al amparo del duque de Angulema, llegó en un forgón del ejército francés que contenía documentos de contabilidad

1825 Agen, autorizado a decir misa, d 1827, 1830 teniente de cura en Laidental, cerca de Burdeos

Será sin duda el mismo que Martín Merino Gómez, natural de Arnedo, guerrillero durante la GI, ya emigrado en Francia en 1819 por liberal, quien había regresado a España en 1820; tras su segunda emigración, volvió a su patria en 1841, siendo agregado en la parroquia de San Justo y capellán de la de San Sebastián en Madrid. El 2 de febrero de 1852 intentó asesinar a Isabel II, por lo que fue ajusticiado el 7 y después se quemó su cadáver. ( $F^{7} 12050$ $\mathrm{n}^{\circ}$ 1623; GNA)

79. MESSEGUER Francisco: n 1781 Albacete, presbítero

1824 Perpiñán, no autorizado a vivir en Marsella: comprometido por su conducta política, mandado a Laval, residencia vigilada, luego mandado a Sées, Normandía junio embarcó en Calais hacia Inglaterra, se le incautó un papel en que constaban 2 canciones: Canción patriótica de la libertad y Marcha del inmortal y generoso Riego $\left(\mathrm{F}^{7} 12024 \mathrm{n}^{\circ} 708\right)$

80. MIRALLES Miguel: párroco en Tortosa

1823 perseguido emigró a Francia después de que fuera incendiada su casa por unos "sicarios"

1831 s Aix-en-Provence: no tenía más que el producto que le devengaba una misa (un franco diario), p 1833, seguía en Aix en 1836, "digno de benevolencia", según el subprefecto $\left(F^{7} 12080 n^{\circ} 225\right)$

81. MOLAS Félix: capellán de tropas constitucionales

1823: Perpiñán procedente de Barcelona, solicitó ir a Marsella $\left(\mathrm{F}^{7} 12015 \mathrm{n}^{\circ} 511\right)$

82. MORAL José del: n 1790, cura párroco de la iglesia de San Ildefonso de Granada 1823 emigró a Francia para "sustraerse a la influencia de los partidos" 1824 Burdeos, 1825 Périgueux cuyo obispo le encargó la parroquia de Ligneux, Dordoña: buena conducta, estimado y" con un nivel de instrucción superior al que suelen tener los clérigos españoles", d 1827 (Guía; $F^{7} 12062 \mathrm{n}^{\circ} 2250$ )

83. MORALEJO José María: n 1770 Colmenar de la Oreja, Toledo, doctor en teología por la Universidad de Alcalá de Henares, cura propio de San Juan en Brihuega, arzobispado de Toledo, 1820 miembro de la Sociedad Patriótica de Malta, autor de un radical Plan de reforma del clero, 1821, miembro de la Sociedad Lanbaburiana en 1822, probablemente masón

1823 emigró a Inglaterra

1831 s Lila, 1832 se trasladó a París, p 1833 pues "los apostólicos no le perdonaban haber publicado 2 folletos, uno sobre la reforma de los regulares, otro sobre la reforma del clero", 1835 publicó un Manuel de conversations françaises et espagnoles, $338 \mathrm{p}$. en $12^{\circ}$, en la imprenta de Casimir; 1836 seguía en París y solicitó un viático para regresar a su patria

1838 profesor en el Instituto de Sordomudos de Barcelona dio a luz, en colaboración con el también profesor Luis Rubió Primeros elementos del idioma castellano. Introducción al arte de leer, 256 p. en $8^{\circ}$, Barcelona, en la imprenta de A. Bergnes; 1844-1845 catedrático de la Universidad de Madrid, Facultad de Teología, todavía con Rubió publicó Arte de leer el idioma castellano, 69 p. en $8^{\circ}$, Barcelona, en la imprenta de A. Bergnes, 1844 ( $F^{7} 12081$ $\mathrm{n}^{\circ} 298$; GNA)

84. MORENO Antonio: n 1775, Salvaltierra, Navarra, cura párroco de Santa María en Tafalla, capellán del regimiento de la Milicia de León, masón espontaneado, enconado liberal

enero de 1824 refugiado en Bayona, mayo Agen, 1825 autorizado a decir misa en una parroquia a $1 \mathrm{Km}$ de la ciudad, estimado por los feligreses, d 1827 (F'11989; GNA; CO)

85. MUÑOZ Antonio: n 1778, Villafranca del Bierzo, León, sacerdote

1824 emigrado por motivos políticos

1831 s Burdeos: total inopia, p 1833 (F>12083 n³48) 
86. MUÑOZ DE SOTOMAYOR: capellán de un regimiento constitucional abril de 1824 pg Sancerre, cerca de Bourges, departamento del Cher ( $\left.F^{7} 11986\right)$

87. MURQUIZ Claudio: n 1773, sacerdote, profesor de humanidades y catedrático de derecho constitucional en Santiago de Compostela

1824 teniente de cura en la parroquia de Petit-Canal, en Grande Terre, Guadalupe 1826 París, s 1832, liberalismo atestado por Alvaro Florez Estrada y Pedro Méndez Vigo, muy digno de interés y el diputado liberal conde de Rémusat procuraba colocarlo de vicario

1833 París asesinó a puñaladas a su posadera Dame Rousseau, española de origen, por conflicto de intereses y deseos de venganza, antes de matarse de un balazo $\left(\mathrm{F}^{7} 12094 \mathrm{n}^{\circ} 1061\right)$

88. NOGUER Rafael: ex religioso, capellán de los hospitales militares constitucionales de Tarragona

1823 Perpiñán, mandado a Laval, residencia vigilada, prefirió volver a España 1827 de regreso a Francia, autorizado a ejercer el sacerdocio en Saint-Laurent de Cerdans, próximo a Perpiñán, pero dio lugar a múltiples quejas por su mala conducta; sus antecedentes políticos le merecieron el apodo de Quiroga $\left(\mathrm{F}^{7} 12014 \mathrm{n}^{\circ} 465\right)$

89. NUÑO Ramón: $n 1778$ Ablitas, Navarra, mercedario exclaustrado

1814 Bayona donde ejerció el sacerdocio durante 5 años, d 1819

1820 regresó a España, fue nombrado párroco de San Ginés en Madrid

1823 de vuelta a Bayona, pretendiendo que sólo se fue en 1820 para recoger una herencia que resultó ser nula y que no tomó parte alguna en los acontecimientos políticos, mas al mismo tiempo confesaba temer ser víctima de persecuciones en España, 1825 seguía en Bayona: buena conducta

1832 Burdeos solicitó ayuda financiera alegando que sólo vivía de limosnas y de algunas misas; le fue denegada puesto que, en realidad vivía con cierto desahogo, era propietario de su casa y tenía un ama de llaves, vestida de manera muy decente; decía misa diaria en Saint-Nicolas de Grave y frecuentaba a varios compatriotas suyos acomodados quienes eran generosos para con él $\left(\mathrm{F}^{7} 12050 \mathrm{n}^{\circ} 1623\right.$ y $\left.12093 \mathrm{n}^{\circ} 968\right)$

90. OCHANDO: 1827 Nantes, eclesiástico español procedente de Lisboa y "perteneciente a la clase de los constitucionales"; buena conducta ( $\left.\mathrm{F}^{\mathrm{1}} 12001 \mathrm{n}^{\circ} 334\right)$

91. OLIVA Pedro: n 1780, en el TL nombrado deán de Tarazona, catedrático de medicina en la Universidad de Valencia

1830 por motivos políticos fue mandado preso a Manila, Filipinas, pero logró escapar antes de embarcar en Cádiz y llegó a Marsella vía Gibraltar y Argel; total inopia, s 1831

1832 Condom, Gers, p 1833 (Guía; F $F^{7} 12080$ n²07)

92. ORTEGA Sebastián: n 1780 Soria, capellán militar

1830 tomó parte activa en la revolución, condecorado con la medalla de Julio, destituido por el arzobispo de París de la parroquia que atendía en la capital francesa, indigencia,

s 1831, p Tolosa 1833, $\mathrm{r}$ febrero de 1834 ( $\left.\mathrm{F}^{7} 12076\right)$

93. PADIERNE Felipe: n 1788 Arnedo, La Rioja, capellán del regimiento constitucional de Infantería de Laredo

1823 pg Aubigny, próximo a Bourges

1824 Inglaterra

enero de 1825 de regreso a Calais, solicitó ir a Montpellier, febrero se le dio permiso de trasladarse a Tolosa, pero murió en Bourges el 28 del mismo, a los 37 años ( $\left.F^{7} 11987\right)$

94. PAONA Bernardo: capellán del ejército de Ballesteros

1823 emigró a Francia

1834 Capion, cerca de Burdeos, ya viejo (sin especificar) y con problemas de salud, sintiéndose incapaz de seguir atendiendo una parroquia rural, pidió al gobierno francés que le diera un sueldo de 2400 francos anuales o que instara a la Reina de España para que le encontrara una colocación en su patria; no consta ninguna respuesta en el expediente ( $F^{\top} 12016$ $\mathrm{n}^{\circ} 2166$ ) 
95. PARNAU José: n 1785 Manresa, Barcelona, hospitalario profeso de la orden de San Juan de Dios, superior administrador general del hospital del Buen Socorro en La Coruña 1830 participó en la expedición de Mina en la frontera, poniéndose a la cabeza de un grupo armado, septiembre emigró a Francia 1832 s Montpellier, p 1833 (F $12090 \mathrm{n}^{\circ} 811$ )

96. PASTOR ZABALA Eduardo: n 1778 Estella, Navarra, 1820 miembro de la Sociedad Patriótica de Logroño capellán de batallón constitucional de la misma ciudad

1823 Marsella, enero de 1824 Alençon, residencia vigilada

Febrero de 1824 Inglaterra ( $\mathrm{F}>12024 \mathrm{n}^{\circ} 710$; GNA)

97. PEÑA Y OLIVA Manuel de la: n 1786 Benaraba, Granada, nombrado en el TL cura párroco de San Roque, diócesis de Cádiz, capellán en el ejército constitucional

1823 Inglaterra

agosto de 1824 tomó parte, como jefe guerrillero, en la tentativa insurreccional liderada por el coronel Francisco Valdes en Tarifa

1827 Portugal encarcelado cuando la entronización de Dom Miguel, liberado en 1830, pasó entonces a Gibraltar, lo mandaron los ingleses a Argel, desde donde zarpó hacia Marsella 1831 s Marsella, p 1833 en el depósito de Tours donde estaba albergado, total inopia (Guía; $F^{7} 12090 n^{\circ} 835$ )

98. PÉREZ Pedro: n 1781, eclesiástico

1830 llegó a París procedente de Calais, "español sin duda refugiado en Inglaterra", no solicitó ninguna ayuda

enero de 1831 obtuvo un permiso de residencia por un año $\left(\mathrm{F}^{7} 12074 \mathrm{n}^{\circ} 2838\right)$

99. PÉREZ MENDO Pedro: n 1783, Badajoz, canónigo doctoral de Badajoz, director de los establecimientos de beneficencia de la misma

1823 condenado por liberal a 8 años de reclusión en un monasterio, escapó a Portugal mas fue encarcelado durante 18 meses por "el usurpador Dom Miguel"

1830 llegó a Francia, 1831 s Burdeos, p 1832, r 1834 (Guía; F¹2079 n 179)

100. PICAS Juan: 1777 Castell de Arenys, Cataluña, cura párroco, predicador de la constitución 1823 Perpiñán, enero de 1824 Laval, luego capellán en el castillo de Fresne-en-Champéon, Mayenne; 1825 Montauban, d $1826\left(\mathrm{~F}^{7} 12026 \mathrm{n}^{\circ}\right.$ 768)

101. PILA Gabriel: n 1780, capuchino exclaustrado noviembre de 1823: tras la capitulación de Barcelona, llegó a Perpiñán, temiendo ser encarcelado por sus opiniones, diciembre r a España ( $\left.\mathrm{F}^{>} 12015 \mathrm{n}^{\circ} 511\right)$

102. PITARCH Manuel: n 1790, Torreblanca, Alicante, presbítero

1823 Perpiñán, no se le permitió vivir en Marsella: comprometido por su conducta política, 1824, Laval y luego Sées, Normandia, residencia vigilada junio de 1824 Inglaterra, se le incautó un texto cifrado cuando el embarque $\left(\mathrm{F}^{7} 12024 \mathrm{n}^{\circ} 708\right)$

103. POSADA Y RUBÍN de CELIS Antonio: n 1768 Soto de Aller, Asturias, 1788 catedrático de cánones en el seminario San Fulgencio de Murcia, canónigo de San Isidro en Madrid, abad mitrado de la Colegiata exenta de Villafranca del Bierzo, 1820 diputado a Cortes por Murcia, masón, nombrado obispo de Cartagena-Murcia en 1821, autor de una Carta pastoral, Murcia, 1822, tachada de furibundo manifiesto revolucionario por los absolutistas; obligado a dimitir de su mitra en marzo de 1825

abril de 1825 Perpiñán, mayo Aix-en-Provence, donde se granjeó la estima del arzobispo a quien ayudó en sus tareas pastorales, 1827 autorizado a viajar libremente en Francia, 1829 la policía de Perpiñán sospechó su participación en una conspiración liberal, pero parece que eran meras conjeturas, $\mathrm{r} 1834$

disfrutó entonces de los favores del gobierno liberal siendo diputado, luego nombrado prócer, arzobispo de Valencia y Patriarca de Indias (Higueruela del Pino Leandro: "El catolicismo liberal en Don Antonio Posada, obispo de Murcia" y Mas Galvañ Cayetano: "El Seminario de San Fulgencio de Murcia (1808-1823): catolicismo, liberalismo y reforma educativa" en 
Libéralisme chrétien et catholicisme libéral en Espagne, France et Italie dans la première moitié du $X I X^{\circ}$ siècle, Université de Provence, 1989, respectivamente p. 361-398 y p. 153-154; CO; DG p.169-184; F 12028 n $^{\circ} 847$ )

104. PUEYO Cristóbal: ex religioso de San Bernardo, capellán de guerrilleros durante la GI 1814 emigró a Francia, teniente de cura en el departamento de Charente, destituido por inmoralidad

1821 volvió a su patria

1824 refugiado en Burdeos, autorizado a decir misa en Saint-Pierre, pero muy malas costumbres, se lo llamaba "el cura casado", también profesaba "las más revolucionarias y odiosas opiniones" y manifestó gran júbilo cuando la muerte de Luis XVIII $\left(\mathrm{F}^{7} 12034 \mathrm{n}^{\circ}{ }^{1020}\right)$

105. QUIJADA Juan José: $n$ 1764 Tudela, Navarra, capiscol en Morella

1823 Perpiñán, comprometido por haber entregado a los constitucionales la platería de su parroquia, vivía de limosnas, "casi tonto"

1824 Agen, albergado en el hospicio donde ejercía su ministerio, conducta sin tacha; 1827 ( $\mathrm{F}^{7} 11989$ y $\left.12026 \mathrm{n}^{\circ} 768, \mathrm{~F}^{19} 5659\right)$

106. RENTERO Martín: n Yecla, Murcia, nombrado cura párroco en el TL y archivero de la Diputación Provincial de Murcia, secretario de la Sociedad Patriótica de la misma, masón, preso a rá́z de los movimientos urbanos en Murcia en diciembre de 1821, luego capellán de un regimiento de caballeria

1823 emigró a Francia, 1828 Lyón, sobreviviendo gracias a una misa diaria en Saint-Pierre, s 1831 , p 1833 (Guía; $\mathrm{F}^{7} 12074 \mathrm{n}^{\circ} 2837$ y 12090 n $^{\circ} 812$; CO)

107. RIERA Juan: n Mataró, Cataluña, franciscano secularizado durante la GI 1815 refugiado en Francia, teniente de cura en Urbanya, cerca de Perpiñán

1824 otra vez en Francia, dio cobijo a un tal Ramón Ferrer, oficial revolucionario, y solía mantener relaciones con otros españoles sospechosos, malas costumbres y malas opiniones políticas

1825 por más que el obispo de Perpiñán lo defendiera, fue expulsado $\left(\mathrm{F}^{7} 12043 \mathrm{n}^{\circ} 1281\right.$ y $\mathrm{F}^{19}$ 5695)

108. ROMEA Policarpio: canónigo de Astorga, diócesis de Tarazona; en el TL fue vicario general castrense del ejército de Ballesteros

1823 Oloron, "revolucionario exaltado",

1824 Saint-Chamond, Loira, conducta irreprochable, indigente, $s$ 1831, $\mathrm{r}$ febrero de 1833

(Guía; $\mathrm{F}^{7} 12016 \mathrm{n}^{\circ} 558$ y $12088 \mathrm{n}^{\circ} 643$ )

109. ROMERO Félix: n Sevilla, presbítero, capellán de un regimiento constitucional

1823 pg Bourges

1831 s Bourges, 1832 Blois $\left(\mathrm{F}^{7} 12079 \mathrm{n}^{\circ} 178\right)$

110. ROYO Joaquín: $n 1781$ Teruel, presbítero, 1820 encabezó un ataque a 110 serviles alzados contra el gobierno constitucional, 1823 encarcelado por 2 años

$1831 \mathrm{Pau}, \mathrm{s}$ pero se le prohibió permanecer tan cerca de la frontera y se lo mandó a Burdeos $\left(\mathrm{F}^{7} 12087 \mathrm{n}^{\circ}\right.$ 620)

111. RUANO Gabriel:n Cartagena, capellán del Real Hospital de la Armada en dicha ciudad, luego capellán de fragata

1823 destituido de sus cargos

1828 emigró a Francia, s Marsella 1831, p 1833 (F¹2080 n²14)

112. RULL José: n 1770 Falzat, Cataluña, presbítero

1823 Perpiñán, comprometido por su conducta política, mandado a Limoges, indigente

1825 ejercía el sacerdocio en Limoges, buena conducta,

1831 s limoges, $p 1833\left(F^{7} 12012 n^{\circ} 428\right.$ y $\left.12106 n^{\circ} 2073\right)$

113. SAEZ de QUINTANILLA Joaquín: presbítero, catedrático de derecho canónico, nombrado rector de la Universidad de Valencia por el gobierno liberal, comunero

1824 emigró a Francia, tras sufrir "encarnizadas persecuciones" 
1832 s Aix-en-Provence, p 1833, con el apoyo de Antonio Posada y Rubín de Celis, atestando que no podía regresar a España sin correr peligro (F $12092 \mathrm{n}^{\circ} 940 ; \mathrm{FB}$ )

114. SALAS Raimundo: 1823 refugiado en Francia

1824 teniente de cura en Frêche, Landas; 1826 destituido, puso pies en polvorosa llevándose algunos efectos mobiliarios que le había confiado el municipio y sin reembolsar cantidades de cierta consideración que había pedido prestadas a distintos habitantes del lugar $\left(F^{7}\right.$ 11993)

115. SICLLIA Mariano José: n 1778, capellán de un regimiento de Infantería durante la GI, canónigo doctoral y prior de la Colegiata de Baza, en el obispado de Guadix; nombrado vicario general de su diócesis durante el TL, 1822 miembro de la Tertulia Patriótica de Baza

1824 emigró a Francia, "comprometido por su adhesión al sistema constitucional", se asentó en Aix-en-Provence: vida retirada y estudiosa, 1825 encargado de la parroquia de Villebon, diócesis de Versalles, publicó distintos manuales de gramática Lecciones elementales de ortología y prosodia, 4 vol. en $8^{\circ}$, París en la imprenta de David, 1827-1828, ampliamente difundidas en América, Diccionario de sinónimos de la lengua castellana, 4 vol. en $8^{\circ}$, París en la Librería Americana, 1827-1828

1831 París, s 1832, r 1833 (Guía; $F^{7} 12023$ n 658 y 12084 n 408; GNA;VA: p. 190 y 198)

116. SIERRA Mariano: 1788 Murcia, capellán de la Armada en Cartagena

1823 emigró a Marsella

1824 Alençon, Normandía, s 1830, p 1833 ( $F^{7} 12021$ n $\left.^{\circ} 626\right)$

117. SOTOS OCHANDO Bonifacio: n 1785, nombrado durante el TL rector del Seminario de San Fulgencio de Murcia, 1821 miembro de la Tertulia Patriótica de la misma, 1822-1823 dipu tado a Cortes por Murcia

1823 emigró a Francia, publicó numerosos manuales de gramática y llegó a ser preceptor de los hijos de Luis Felipe (Guía; GNA)

118. TENA Miguel: n 1785 Llivia, Cataluña, presbítero

1823 emigró a Marsella y fue mandado a Alençon

1828 encargado de la parroquia de Chevain, Sarthe, s 1831 pero subsidio suprimido en 1832 puesto que cobraba 800 francos anuales como teniente de cura; 1833 solicitó el permiso de permanecer en Francia, donde tenía un empleo, lo que le fue concedido, pero dejaba de ser un refugiado, por consiguiente ya no podría disfrutar de ayuda financiera alguna $\left(F^{7} 12024 n^{\circ} 689\right.$ y $\left.12085 n^{\circ} 500\right)$

119. TOLEDO Matías: $\mathrm{n} 1788$, capellán de un regimiento constitucional 1823 pg Bourges

1824 procuró entrar en Italia, pero fue rechazado, junio Draguignan ( $F^{7} 11987$ )

120. TORNER Buenaventura: n Barcelona, presbítero, febrero de 1823 miembro de la Tertulia Patriótica de Barcelona

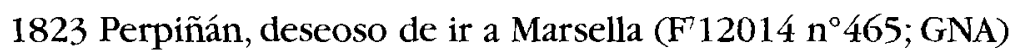

121. TORRE Manuel de la: doctor en teología, cura párroco de San Justo y Pastor en Segovia, 1820 miembro de la Sociedad Patriótica de la misma

1826 perseguido por el obispo de Segovia, por motivos políticos, llegó a Bayona al amparo de Amédée Guyot, ayudante de los hospitales militares franceses, como supuesto criado suyo; se instaló en Montpellier (Guía; $\mathrm{F}^{\top} 12064 \mathrm{n}^{\circ}$ 2351)

122. ULLE Camilo: n 1785 Barcelona, presbítero, predicó la constitución, capellán de tropas constitucionales

noviembre de 1823 Port-Vendres, deseoso de ir a Marsella; parece que regresó a España en diciembre (F $712015 \mathrm{n}^{\circ}$ 511)

123. VALLEJO Angel: ex religioso, capellán de un regimiento constitucional sf emigró a Francia, huyendo del "despotismo monacal"

1833 Tolosa, "arbitrariamente destituido por el arzobispo de su cargo de teniente de cura en la parroquia de Vigoulet, pidió una ayuda financiera, mas no le fue otorgada pues era pro- 
pietario de una casa de pueblo y de una alquería, además de tener sus ahorritos $\left(\mathbf{F}^{7} 12105\right.$ $\mathrm{n}^{\circ}$ 2050)

124. VICTORINO Manuel: n 1782 Mérida, nombrado canónigo de Badajoz durante el TL 1823 comprometido por su adhesión al sistema constitucional, se refugió en Portugal 1825 desembarcó en Le Hâvre, procedente de Lisboa, y se instaló en Burdeos, donde su hermana, viuda con 3 hijos, poseía una considerable fortuna (Guía; $\mathrm{F}^{\prime} 12051 \mathrm{n}^{\circ} 1699$ )

125. VIGUER Juan: $\mathrm{n}$ Granollers, Cataluña, dominico exclaustrado, 1822 miembro de la Tertulia Patriótica de Barcelona

1824 Perpiñán, comprometido por liberal, mandado a Montauban: buena conducta, autorizado a decir misa, d 1825 ( $F^{7} 12034 \mathrm{n}^{\circ} 1027$ y $\mathrm{F}^{19}$ 5688; GNA)

126. VILA Antonio: sacerdote, profesor de la Universidad de Cervera, predicador de la constitución y redactor de $\mathrm{El}$ Indicador Catalán, periódico exaltado

1823 desembarcó en Port-Vendres, deseoso de ir a Tolosa, mandado a Laval en enero de 1824 , pero parece que intentó regresar a España $\left(\mathrm{F}^{7} 12015 \mathrm{n}^{\circ} 511\right)$

127. VILLUENDAS Ramón: 1787 Albarat, Valencia, presbítero

1827 refugiado en Francia, por motivos políticos

1832 s Burdeos: indigente tan sólo tenía el producto de alguna que otra misa, p 1833 (F? $\left.12094 \mathrm{n}^{\circ} 1075\right)$

128. VINCENT Andrés: $\mathbf{n} 1792$ Valencia, capellán del regimiento de Voluntarios de la misma 1823 pg, 1824 enfermo en el hospital de Agen, 1825 d en Dordoña donde el obispo de Périgueux lo había nombrado teniente de cura en una parroquia, buena conducta $\left(\mathrm{F}^{7} 11989\right.$ y 12026 $\mathrm{n}^{\circ} 768$ )

129. XIMÉNEZ MARCOS Agustín: n 1776, Eibar, Navarra,capellán de la fortaleza de Pamplona, opiniones políticas tan exaltadas que ya estaba recluido cuando entró el ejército francés en Pamplona y había suscitado tanto odio que fue preciso excarcelarlo muy de madrugada para evitar alborotos

diciembre de 1823 pg en el fuerte de Briançon por "peligroso"

1824 Agen, expulsado pero en 1826 todavía permanecía escondido en la región de Pau, dedicándose a copiar la prensa liberal francesa

1827 se embarcó en Bayona con rumbo a Portugal, gracias a una colecta organizada entre sus compatriotas residentes en dicha ciudad para pagar su pasaje $\left(\mathrm{F}^{7} 11989\right)$

130. YRLAR'TE Juan: capellán de un regimiento constitucional $1823 \mathrm{pg}$

1824 solicitó residir en Burdeos, pero el arzobispo no permitió que dijera misa, pues el haber sido capellán del ejército liberal significaba que tenía "malos principios" ( $\left.F^{7} 11986\right)$ 
